IZA DP No. 7920

From Aliens to Citizens:

The Political Incorporation of Immigrants

Pieter Bevelander

Mikael Spång

January 2014

Forschungsinstitut

zur Zukunft der Arbeit

Institute for the Study

of Labor 


\title{
From Aliens to Citizens: The Political Incorporation of Immigrants
}

\author{
Pieter Bevelander \\ MIM, Malmö University \\ and IZA \\ Mikael Spång \\ Malmö University \\ Discussion Paper No. 7920 \\ January 2014 \\ IZA \\ P.O. Box 7240 \\ 53072 Bonn \\ Germany \\ Phone: +49-228-3894-0 \\ Fax: +49-228-3894-180 \\ E-mail: iza@iza.org
}

Any opinions expressed here are those of the author(s) and not those of IZA. Research published in this series may include views on policy, but the institute itself takes no institutional policy positions. The IZA research network is committed to the IZA Guiding Principles of Research Integrity.

The Institute for the Study of Labor (IZA) in Bonn is a local and virtual international research center and a place of communication between science, politics and business. IZA is an independent nonprofit organization supported by Deutsche Post Foundation. The center is associated with the University of Bonn and offers a stimulating research environment through its international network, workshops and conferences, data service, project support, research visits and doctoral program. IZA engages in (i) original and internationally competitive research in all fields of labor economics, (ii) development of policy concepts, and (iii) dissemination of research results and concepts to the interested public.

IZA Discussion Papers often represent preliminary work and are circulated to encourage discussion. Citation of such a paper should account for its provisional character. A revised version may be available directly from the author. 


\section{ABSTRACT \\ From Aliens to Citizens: The Political Incorporation of Immigrants}

This is a draft chapter for the Handbook on Economics of International Migration (Eds. B. R. Chiswick and P. W. Miller) and deals with the political incorporation of immigrants in host societies. Political incorporation is discussed with regard to the regulation of legal status, rights, opportunities, and acquisition of citizenship. We give examples of the legal regulation and policies from several countries in the world, showing thereby the diversity of approaches to political incorporation but also similarities to the regulation of access to residence, rights, and citizenship. We highlight changes in this regard since the Second World War and discuss more recent trends. Moreover, we discuss different factors explaining the variation in incorporation policies. Also, this chapter traces different dimensions of political participation of immigrants, and, finally, we address the expected effects on wider integration of citizenship acquisition.

JEL Classification: D72, J15, J61

Keywords: citizenship, naturalization, political incorporation, immigration, minorities, political participation, non-citizens, rights

Corresponding author:

Pieter Bevelander

MIM

Malmö University

20506 Malmö

Sweden

E-mail: pieter.bevelander@mah.se 


\section{Introduction}

Participating in politics and, more generally, in social, economic, and cultural life is central to modern democracy, which has emerged out of struggles for inclusion of the poor, women, the working class, minorities, indigenous peoples, and, more recently, immigrants. The overall trend in democratic immigration states since the Second World War is towards increasing equality between citizens and non-citizens and towards easier access to citizenship.

Access to legal status, rights, and opportunities for immigrants has followed a democratizing logic, but it also differs from several of the earlier inclusion processes. Recognition of immigrants' rights has followed less upon claims made by social movements than through decisions made "behind the closed doors of courtrooms and state bureaucracy" (Joppke, 1999, p.3). When rights have become more established in laws and institutional practices, however, immigrants have made use of their opportunities to take part in politics and have been active in defending and expanding rights and opportunities, albeit in varying degrees (Guiraudon, 1998; Koopmans, et al., 2005).

Over the past decade, there have been signs that the inclusion and expansion processes are coming to a halt, even though the signs are at times conflicting. Right-wing populist mobilization against immigration has led to debates about restricting access to rights and making naturalization more difficult. Criteria for residence have become more restrictive, and new conditions have been imposed on the acquisition of citizenship in several countries (Joppke, 2010). The multicultural approach to integration has been criticized over recent decades, with established politicians increasingly voicing this criticism (Joppke, 2010; Kastoryano, 2010; Kymlicka, 2012). In the wake of the September 11 attacks, the protection of civil rights has been curtailed in several states, and it has had obvious effects on immigrants, for instance, regarding detention and expulsion (Costello, 2012; Fraga 2009). Furthermore, states have increasingly introduced the possibility of depriving persons of citizenship, both those who have citizenship from birth and by naturalization. In Denmark, for instance, persons convicted of certain crimes against the state may be deprived of citizenship unless this would make the person stateless (Ersböll, 2010, p.20).

To what extent this shows the beginning of a reversal of the inclusionary logic is difficult to tell. The political situation today is very different from that of a couple of decades 
ago, but more extensive reversals of the process of extending rights and opportunities are perhaps less likely. Aside from the entrenchment of legal status, rights, and opportunities in democracies, immigration being likely to increase rather than decrease globally may also be a factor (Hollifield, 2004). Furthermore, as Cornelius et al. noted in the early 1990s, there is a gap between restrictions and continued acceptance of immigrants (Cornelius et al., 1994). Whereas research has shown the gap between policy and practice in immigration policy is not wider than in most other policy fields, there are clear differences between restrictionist rhetoric and adopted policies and laws, as well as between what is legislated and how this is interpreted by courts and implemented by bureaucracies (Bonjour, 2011; Freeman, 1994; Joppke, 1998a).

In this article, we focus on the political incorporation of immigrants. Political incorporation is a subset of societal integration as it also involves labor market participation and access to housing, education, social security, public services, and cultural life (Bommes \& Geddes, 2000; Kivisto \& Faist, 2007; Freeman, 2004; Hochschild \& Mollenkopf, 2009). These fields are related as opportunities for participating in politics depends on, for instance, socio-economic inclusion. Resources like income, time, knowledge, and networks affect opportunities for people to take part in politics. Differences with regard to integration policy, such as assimilation and multiculturalism, also affect the opportunities for political participation as well as the mode of participating (Bloemraad, 2006a; Freeman, 2004; Koopmans et al., 2005; Kymlicka \& Norman, 2000). Even though access to such things as jobs and schools often matters most to individuals, political incorporation also has a special importance. By taking part in politics, it is possible both to change the distribution of resources and opportunities in society and to challenge power relations, norms, and attitudes. Being excluded from politics is to lack an important tool to change one's situation as well as that of others (Bohman, 1996; Dahl, 1989). The interrelationship between political incorporation and other forms of inclusion suggests we take a broader look at political incorporation. However, it is beyond the scope of this paper to deal with socio-economic and cultural inclusion in detail. Nevertheless, in the following, we will highlight some important dimensions in this regard relating both to the impact of resources and mode of participation as well as to the consequences of different integration regimes.

We begin the article by discussing access to legal status (residence), rights, opportunities, and the acquisition of citizenship. Access to rights depends partly on entry 
conditions; immigration policy matters for incorporation policies (Freeman, 2006). We address these dimensions by describing the regulation of access to legal status and rights between different groups of immigrants, the regulation of citizenship acquisition, and the recognition of dual citizenship (multiple citizenships). Factors of relevance in explaining differences in incorporation policies will be discussed in the second section. We then focus, in the third section, on the political participation of immigrants concerning voting and other forms of participation and claim-making in the public sphere. Citizenship is important to social and economic integration, and we address debates and research on the citizenship premium in the fourth section.

\section{Contemporary Policies of Immigrant Political Incorporation}

This section deals with the legal and political regulations of the status of immigrants, access to rights, eligibility for acquiring citizenship, and conditions tied to naturalization as well as the regulation of multiple (dual) citizenships. These are all important dimensions of the political incorporation of immigrants. We start by discussing the situation for long-term residents; we then address the regulation of access to rights for other categories of immigrants, such as seasonal workers, persons with temporary protection, and undocumented migrants. After this, naturalization rules, acquisition of citizenship by socialization for second-generation immigrants, and the question of multiple nationalities are considered before we explain similarities and differences between incorporation regimes.

\subsection{Legal Status and Access to Rights for Long-term Residents}

Access to legal status and rights for non-citizens have, since the Second World War, become increasingly equal to that of citizens in Western democratic immigration states. This becomes particularly clear when long-term (permanent) residents and citizens are compared. The major differences between non-citizens and citizens concern the rights for citizens to vote (in national elections) and to stand for office as well as the unconditional right to enter and reside in the state (Castles \& Davidson, 2000, chapter 5; Kivisto \& Faist, 2007).

The introduction of the category 'permanent resident' is itself an example of the strengthened status for immigrants. This category is in several democratic immigration states 
of rather recent origin; in many countries in Europe it was established as part of the response to post-war labor immigration, when guest workers were not returning home (Hammar, 1990, pp.18f). The development towards strengthening the status of non-citizens and their access to rights has made several scholars emphasize the importance of jus domicilii in democratic immigration states. Tomas Hammar (1990) used the notion of denizen to characterize this situation: a strong protection of rights but not a full inclusion in the political community. Examples of this process towards a strengthening of legal status and access to civil and political rights have occurred in several immigration states in Europe. Prior to the Second World War, it was commonly argued that non-citizens should not have rights to participate in politics, and the right to form associations was denied to foreigners, as was, in many cases, the right to engage in political speech. The political participation of foreigners was thought to constitute security problems, problems of foreign policy, and risks regarding the import of political conflicts. However, these views gradually changed in many democratic immigration states after the Second World War, and it was more generally recognized that non-citizens should enjoy the same political rights (except the right to vote) as citizens (Groenendijk et al., 1998; Guiraudon, 1998; Hammar, 1990; Waldrauch \& Hofinger, 1997).

In the Nordic states, non-citizens were afforded the same civil and political rights (except for voting) as citizens in the 1950s and the 1960s. Similar developments are found in other west European states. In 1953, foreigners were given the right to take part in demonstrations and associations in the Federal Republic of Germany, and in 1964 they were afforded the right to form their own associations. A couple of years later, non-citizens got the right to become members of political parties. In some European states, this process was drawn out; it was only in 1981 that non-citizens were granted the right to form their own associations without permission by the state in France. Prior to 1981, the expulsion of persons active in unions and human rights associations was possible, and many immigrants were expelled for their political engagement, which was seen as disrespecting the political neutrality of foreigners in the country (Guiraudon, 1998; Hammar, 1990, chapter 8).

Voting rights for non-citizens have remained much more controversial than other political rights. In most states, only citizens have the right to vote in national elections. ${ }^{1}$

\footnotetext{
${ }^{1}$ An interesting exception to the common pattern of tying the right to vote to citizenship was the practice in the US of allowing the right to vote for several non-citizens, something that ended only in 1926, when the last state (Arkansas) that had kept alien franchise changed the rules (Coll, 2011).
} 
However, steps towards recognizing voting rights were taken in some countries during the 1970s (cf. Hammar, 1990, chapter 8). Local and regional voting rights were recognized in Sweden in 1975. In Norway, voting rights were granted in local elections for other Nordic citizens in 1978 and extended to all permanent residents in 1983. The same pattern is found in Denmark, where voting rights in local and county elections were granted for Nordic citizens in 1977 and extended to all permanently residing non-citizens in 1981. Similar processes are found in several other countries in Europe; in the Netherlands, local voting rights were recognized for non-citizens in Rotterdam in 1979, and this was expanded to the whole country in 1985. More recent examples of introducing local voting rights include Finland (1991), Iceland (2002), Slovenia (2002), and Luxembourg (2003) (Groenendijk, 2008; Hammar, 1990, chapter 8).

Most European states today recognize the right to the status of permanent resident (Groenendijk et al, 1998; MIPEX, 2010). The criteria for permanent residence vary between states stipulating few requirements, such as in Sweden, and states in which acquiring permanent residence is almost as difficult as becoming a citizen, such as Denmark and Germany (MIPEX, 2010).

In most states, some period of legal stay in the country is required, ranging from three years in France and five years in several states (such as Denmark, Italy, Germany, Netherlands, Poland, and United Kingdom) to states that require longer stay, for instance, eight years in Portugal. Several states, such as Sweden, grant permanent residence for certain groups, such as refugees, from the beginning of their stay. Most European states apply additional criteria, such as ensuring persons are able to support themselves; some states apply extensive criteria in this respect. In Denmark, persons need to be working or studying at the time of application, show they have studied or have had full-time employment for three out of five years prior to application, and demonstrate they have not received certain types of public benefits three years prior to applying (Ersböll, 2010; Groenendijk et al., 1998; MIPEX, 2010). Another set of requirements that vary between states concerns public order. Denmark is among states with restrictive regulation in this respect: persons who have been in jail or have been sentenced to jail for more than 18 months are disqualified from being able to apply for permanent residence in Denmark. When sentenced to less than 18 months in jail, persons are temporarily ineligible for applying according to a waiting list. Such waiting lists are used in several European states. Some states require knowledge of language and society; for instance, 
in Germany, persons need to have command of the German language and to have knowledge of German society. Similarly, in Denmark, persons need to pass a Danish language test (Ersböll, 2010; Hailbronner, 2010; Groenendijk et al., 1998). Newer regulations in the UK require that persons have command of English (Sawyer, 2010).

The situation in the UK has been different from most states on the European continent because of the Commonwealth association, particularly since the status of British subject, with the right to live in the UK, was applied until the 1981 nationality law. The equivalent to permanent residence in the UK is the so-called indefinite leave to enter or remain (ILR). The somewhat peculiar dimension to this status is that persons who require a leave to enter permit acquire it. Formally, the status is lost when leaving the UK and must be re-established when re-entering the country. For shorter periods of time abroad, this is a formality, but the status of ILR is usually lost when staying abroad for a longer time (e.g., two years) (Groenendijk et al., 1998, pp.59f).

In some European states, such as France and Germany, the development towards recognizing permanent residence for immigrants has been a process in which courts have played an important role. Even though political parties in Germany were less prone to follow the steps towards recognizing rights for aliens in the 1970s, rights for aliens were recognized due to interpretations of the Constitutional Court, which recognized that aliens enjoy rights of free movement and choice of profession similar to citizens on the basis of the Basic Law's article (2(1)) on the free development of personality. The Court argued also that non-citizens, after some time and when return has become less likely, have a legitimate expectation that the German state protect their rights. In the so-called Indian case in 1978, the Court ruled that when authorities renew residence permits, this gives rise to an interest on the part of aliens to continue to be granted residence after some time. Later, the Court ruled also that residents could not be deprived of enjoyment of pension payments when residing in the state. In line with the constitutional principle of Germany being a social state (Sozialstaat), the Court ruled that this applies to all-irrespective of nationality (Joppke, 1998b, chapter 6; Guiraudon, 1998, pp.299f). Local voting rights have also been discussed in Germany: Schleswig-Holstein granted local voting rights to Danish, Irish, Norwegian, Dutch, Swedish, and Swiss citizens in 1989, and Hamburg approved local voting rights for residents who had resided for eight years. However, the Constitutional Court struck down on both decisions, arguing they were contrary to the Basic Law, which entails only German citizens (Joppke, 1998b, pp.194ff). 
Courts played an important role also in France. Before the late 1970s and early 1980s, courts had little say vis-à-vis the manifold decisions, decrees, and other instructions issued by government. However, from the late 1970s and onwards, the Council of State declared many of the previous regulations invalid, and it-together with the Constitutional Council-has played an important role in strengthening and upholding the status and rights of non-citizens, for instance, through its decision in 1989 that non-citizens could not be excluded from non-contributory benefits (Guiraudon, 1998, pp.298f). The current residence permit was introduced in 1984; additional requirements restricting the number of immigrants who could enjoy this permit were made by center-right governments and then revoked by socialist governments in the 1980s and 1990s (Groenendijk et al., 1998, pp.31ff). Rights for noncitizens in local elections have been discussed since the early 1980s, and the socialists at the time included it in their party platform but chose not to push for the issue because it would likely not have been approved by the senate. This is what happened to a bill introduced in 2000: after being accepted in the national assembly, it was later defeated in the senate (Bertossi \& Abdellali Hajjat, 2012).

In other states, such as Sweden and the Netherlands, the process towards recognizing permanent residence has been political in nature. Courts play a less important role in both countries; instead, political parties and state administrations have been important actors. In Sweden, avoiding a guest worker system by stressing equal opportunities and equal living standards for citizens and immigrants in the 1960s provided an impetus for a politically driven process towards jus domicilii (Hammar, 1990).

Another example of a politically driven process, although relying to a large degree on the jurisprudence of the EC court, is the recent changes in several European states_e.g., Belgium, Italy, Portugal, and Spain-because of the EC directive 2003/109 on the status of long-term residents. The special residence permit for long-term residents in Spain was first introduced in 1996 (Groenendijk et al., 1998, pp.53f). In Italy, it dates back to 1998; prior to this, only a spouse of an Italian citizen could be granted permanent residence (Groenendijk et al., 1998, pp.77f). In 2007, the EC residence permit for long-term residents was introduced in Italy, and legal regulation of permanent residence was changed in Portugal that year through a new immigration law (MIPEX, 2010). In Belgium, the 1980 Aliens Act introduced the establishment permit, intended to give a secure status for long-term residents or persons having close ties with persons living in Belgium. This regulation entailed a significant shift vis-à-vis earlier practice; lawful use of freedom of speech and association was 
no longer grounds for expulsion (Groenendijk et al., 1998, pp.20ff). Belgium has also changed the legal regulation of permanent residence in line with the EC directive (MIPEX, 2010).

The changes in residence regulation and access to rights for non-citizens in several European states after the Second World War show the development of jus domicilii, which entails that citizens and non-citizens should be treated equally when there are no legitimate reasons for differential treatment. This type of reasoning has for a long time been the basis for inclusion of aliens in the US (Joppke, 1999, pp.22).

US incorporation laws and policies are constitutionally based on two principles: the principle of plenary power and the principle of personhood. Plenary powers entail federal bodies having the right to enact laws and make decisions that are not subject to judicial review. This has been the basis for Congress adopting laws relating to regulating immigration and access to rights. The principle of personhood entails non-citizens being equal to citizens in most respects. This principle has influenced the treatment of non-citizens over the past couple of decades, with the civil rights movement being important in bringing out this idea with regard to immigrants. The Supreme Court argued in the early 1970s (Graham $v$ Richardson, 1971) that aliens, like citizens, pay taxes and work, meaning that they should be treated like citizens. This recognition of non-citizens led to courts striking down several laws that restricted their rights in the 1970s. However, the principle of plenary power was not repealed and was ground for restricting rights for non-citizens through the Welfare Reform Act in 1996. Through this legislation, access to social rights and federal welfare programs was restricted for non-citizens (Schuck, 1998, pp.202ff).

Permanent residence in the US is less beneficial and secure than in most other democratic immigration states, and it may be revoked for several reasons, including for minor crimes, for tax evasion, and for stays outside of the country longer than 6 months. Decisions concerning deportation do not need to be balanced with regard to personal circumstances tying persons to the US (MIPEX, 2010, pp.210). In Australia, persons may apply for a permanent residence visa according to the different routes of entry for work, business, and the like. Visas are valid for five years, allow persons to leave and return, and give access to several social rights (Castles \& Vasta, 2004). Canada also utilizes several routes for entry, such as for study, work, and business; beside the basic rules for eligibility, a points system is applied where such factors as language, age, and work experience count. This system was 
introduced in 1976, replacing previous legislation based on source countries and regional criteria (Reitz 2004). Access to residence status is relatively easy in Canada, and it is often given from early on in the settlement process. Further, family members and refugees are automatically eligible for permanent residence (MIPEX, 2010, pp.48).

The situation of permanently residing immigrants has been strengthened in some countries in Africa, Asia, and Latin America, but it remains precarious in several states. Most Latin American states allow for permanent residence. In Chile, persons can apply for permanent residence after one year (two years when on a work visa), and it is necessary to show that persons can support themselves; similar rules apply in Uruguay. Some states require a longer stay, for instance, three years in the case of Argentina and five years in Mexico. In Argentina, persons are required to have knowledge in Spanish and about society (US Government, 2001).

In most East and Southeast Asian states, permanent residence is primarily offered to high-skilled and professional immigrants, whereas the vast majority of low-skilled migrants do not have access to permanent residence status. In addition, many persons live and work as irregulars (Piper, 2004). Access to secure legal status and rights remain a problem for migrant workers; the guest worker system and lack of family reunification policies in several East and South-east Asian states show the conception of transition from alien to citizen is not envisioned and does not provide the basis for policy and legislation (Piper, 2004, pp.79f). Japan is also partly an example of this kind of reasoning. The unresolved status of Koreans, who had enjoyed Japanese nationality during the empire but were defined as non-citizens after the Second World War, led to the creation of the status of special permanent resident in the 1980s. The return migration of Japanese from China, labor immigration, and the acceptance of refugees (even though limited in number) were important in establishing the category of long-term resident. As will be touched upon below, the introduction of the status of legal resident has been explicitly tied to deterring immigrants from becoming citizens (Surak, 2008).

\subsection{Access to Rights for Other Non-Citizens}

The equalization of non-citizens and citizens is far less evident in other cases than long-term residents. Seasonal workers and persons having work permits for limited periods of time lack 
several rights enjoyed by permanent residents. Several European states have wanted to avoid the consequences of post-war labor immigration when setting up new programs for labor immigration; as a result, they have restricted access to resident status. A maximum period of residence and a preclusion of the possibility for family reunification are examples of measures adopted for this purpose (Menz \& Caviedes, 2010).

With regard to asylum, granting short-term protection has become more common. The civil wars in former-Yugoslavia during the early 1990s were important in the European context for the development towards temporary protection. The introduction of short-term protection caused intense public debate in several European countries, and there were fears that this would be used in many more cases than 'mass flight situations,' for which the category was originally devised (Fitzpatrick, 2000; Koser \& Black, 2003)

In general, asylum seekers enjoy fewer rights than other immigrants (Gibney, 2004). Administrative detention, often in the case of extradition but also during the asylum determination process, includes severe limitations of civil rights (cf. Costello, 2012). Deportation is, on the one hand, a form of extended border control in which states deport persons who have entered the state without proper documentation, visa over-stayers, and asylum seekers whose application has been denied. On the other hand, deportation is used also for expelling persons who have committed crimes, which, according to some scholars, make non-citizens 'eternal guests' in the state (Anderson et al., 2011).

Another problem is the legal status of persons in so-called transit zones, which are within geographical borders of the state but are not acknowledged by authorities to be on their territory. One example is the zone at the Paris Charles de Gaulle airport, where persons, including children, are held in custody by French authorities but where French law does not apply (Human Rights Watch, 2009). The UN Rapporteur on the rights of non-citizens criticized international zones in the early 2000s for being 'legal fiction,' emphasizing that states cannot disregard their obligations in this manner (United Nations 2003).

The situation for undocumented migrants is also difficult in many countries, and their access to rights is limited (Sager, 2011). Several states in Europe-such as Belgium, Ireland, Italy, Poland, Portugal, Spain, and the UK—grant the right to education for children in an irregular situation, whereas others, such as Sweden, do not. The Swedish government has declared its intention to implement this right, but it has not yet put forward a bill to 
parliament. In several countries, such as Germany and France, the right to education is implicitly guaranteed; however, in practice, there are several obstacles to this right. In Germany, schools are required to report irregular status to authorities. The right to health care for irregular migrants is also recognized in several European countries, but it is most often limited to urgent medical treatment. In some states, health care includes preventive care, such as prenatal and maternity care, care for children, and vaccinations; this is the case in Germany and Italy. In a few states, such as Portugal, children are afforded the same rights to health care as regular residents and citizens (Fundamental Rights Agency, 2011).

\subsection{Naturalization}

The effects of naturalization legislation and policy differ from being an easy and inexpensive procedure with rather few conditions in some states to a difficult, costly, and cumbersome process to become a citizen in other states. Acquisition of citizenship has traditionally been easier in Australia, Canada, and the US than in Europe, but some of the most liberal countries today are found in Europe. For a long time, rules regarding naturalization were made less restrictive in several immigration states, but this liberalization process has partly been reversed over the past decade (Joppke, 2010).

There are several routes for becoming a citizen, and the focus in this section is on the general naturalization rules. Spouses and partners can commonly acquire citizenship more quickly and easily than several other types of immigrants. The acquisition of citizenship for refugees is also easier in several states, and several states outline preferential treatment of persons on the basis of origin. What is often called socialization-based acquisition of citizenship by second-generation immigrants is discussed in the section below.

Common criteria for naturalization are length of stay and good character; the latter is determined through, among other things, criminal records and an adequate livelihood. Several states also require immigrants take language tests or show adequate knowledge of language in other ways, as well as tests regarding knowledge of society. Some states require a declaration of allegiance and loyalty to the state (Castles \& Davidson, 2000, pp.86ff; Goodman, 2010). 
Among the most liberal rules regarding the length of stay today are found in Australia and Canada, where four years of legal residence is required. In Australia, the required length of stay was changed with the 2007 Citizenship Act from two to four years, and in Canada it was changed in 2009 from three to four years. In both countries, 12 months of absence is allowed. In Australia, persons must have resided in the country for at least 12 months immediately before applying. Both countries have good character requirements and both require knowledge concerning language and society. In Canada, knowledge of the country-especially the rights and obligations of citizenship-is required, as well as proficiency in English or French. This criterion does not apply to persons who are above fiftyyears-old. Persons who have been convicted of crimes in the most recent years before applying are not eligible to apply. In Australia, persons must provide an overseas police clearance certificate when applying for citizenship; moreover, applicants need to pass a citizenship test (MIPEX, 2010). Becoming a US citizen requires five years of legal residence when a green card holder; 30 months of physical presence in the country immediately before applying; being able to read, write, and speak English; passing a test on knowledge regarding society and government; and showing good moral character (Schuck, 1998, pp.201f).

The most liberal naturalization regulation in Europe is found in Belgium, where the residence requirement was lowered in 2000 from five to three years and where earlier requirements regarding language skills (called willingness to integrate) were abolished. Some other states also have rather liberal naturalization laws; according to Marc Howard's citizenship policy index (CPI), states like France, Sweden, and the UK have liberal policies, whereas Austria, Denmark, Greece, and Spain belong to states with restrictive rules (Howard, 2009). In the Migrant Integration Policy Index (MIPEX, 2010), Portugal, Belgium, Sweden, the Netherlands, and Italy are placed before France and the UK. In the case of the UK, it has significantly dropped in ranking from the previous MIPEX report due to legal changes in 2009 (MIPEX, 2010, pp.22f and 205).

Several European states require five years of residence before naturalizing, but some states require a longer stay, for instance, up to twelve years in Switzerland. Among states requiring only five years of residence are Bulgaria, the Czech Republic, France, the Netherlands, Poland, Sweden, and the UK. Among those requiring a longer stay are Austria, Denmark, Greece, Norway, Germany, Hungary, Italy, and Spain. The length of residence is in several states further qualified by requirements of uninterrupted stay prior to application. 
Some states, such as Bulgaria, the Czech Republic, Greece, Latvia, and Poland, only count years as a permanent resident when determining whether a person is eligible for applying, and, in some other states, some of the years of required residence need to be on the basis of a permanent residence permit. One example of this is Austria, which requires five out of ten years as a permanent resident (Goodman, 2010, pp.6ff).

All states in Europe have requirements that relate to one's criminal record, and most states include requirements concerning one's financial situation as well as 'good character' or similar. Some states have very strict requirements in this respect. In Austria, persons convicted of any crime will not be granted citizenship. In Denmark, it is not possible to become a citizen when a person has served more than 18 months in prison (or only 2 months of imprisonment if the crime related to national security). Other states include one's criminal record among the parameters of decision but do not rule out becoming a citizen if convicted of crimes. Instead, persons most often need to wait before being able to apply, with the severity of the crime determining the waiting period. Several states require persons to support themselves, and some states require persons not being dependent on welfare. Some, albeit few, states in Europe have health requirements for becoming a citizen (Goodman, 2010, pp.11ff)

Today, knowledge of language is required in several European countries, as is knowledge of society (Goodman, 2010; Joppke, 2010). Whereas Belgium, Ireland, Italy, and Sweden do not require knowledge of language, many other states do, testing it through interviews and/or written tests. Some states require a language certificate to be provided when applying for citizenship. Denmark, France, Germany, the Netherlands, and the UK also require knowledge of society. In Denmark and the Netherlands, tests of language and knowledge have recently been made more restrictive; tests are now formalized whereas they were previously done through interviews with civil servants (Goodman, 2010, pp.13ff; de Hart \& van Oers, 2006).

In most European states, administrative authorities handle applications for citizenship, but there are some exceptions to this. In Denmark, each application for citizenship is addressed by the parliament naturalization committee and accepted or not through parliamentary decision. The right wing populist Progress Party and, later, the Danish People's Party used this avenue as a way to oppose individuals whom they thought would not be suitable citizens. They thereby made the criteria for becoming a citizen a central political 
issue (Ersböll, 2010, pp.15ff). In Switzerland, the process is partially political; in some cantons, decisions regarding citizenship are taken by a local vote (D’Amato, 2009; Hofhansel, 2008, pp.181ff).

The more restrictive rules introduced in several European countries reflect a debate concerning a failure of integration and an increasing emphasis on belonging. The introduction of new conditions for citizenship shows a change from perceiving citizenship as a means for integration to viewing it as the culmination of successful integration. Citizenship is looked upon more as a privilege, as a political good that must be earned rather than granted as a matter of right (Joppke, 2010, pp.54ff). Besides increasing the required length of stay, new language and knowledge tests are primarily discussed in this context. Most of the tests of knowledge regarding society focus on politics, economy, and the provision of public goods and services. Only minor parts of the tests relate to traditions and public morality. Among countries including knowledge of public morals, the Netherlands is an example where these types of questions play an important role (16 percent of the questions concern public morality); conversely, it is not as central in Austria and Germany (Michalowski, 2011).

In the debate regarding language and knowledge tests, it has been common to associate such tests with nationhood and the overall characteristics of the citizenship regime, but, as shown in comparative studies, this does not hold true. In her research on citizenship tests, Ines Michalowski concludes that the common assumption-that knowledge tests in countries with restrictive citizenship regimes focus on cultural assimilation-does not hold (Michalowski, 2011). This confirms Joppke's interpretation of citizenship tests, in which he stresses that, rather than to see tests as attempts of re-ethnicization of citizenship, they are better viewed as a form of repressive liberalism or "particular universalism” (Joppke, 2010, pp.137ff). Language and knowledge tests are not primarily focused on particular traditions and values but on universal values: equality, freedom, gender equity, and tolerance. In citizenship tests, these values are rendered national (e.g., Dutch) values, specifying what it entails to be a citizen in a specific state. Consequently, it is not appropriate to see the trend towards making it more difficult to naturalize as another attempt to stress the ethnic, cultural, and linguistic particularities of the nation, Joppke has argued. Instead, it is a form of exclusion built on universal values that not all persons share and/or understand (Joppke, 2010, pp.123144). 
Despite this trend towards increasing restrictions being evident in Europe over the past decade, there is, using a somewhat longer time perspective, a trend towards liberalization. Joppke estimates that, since the 1980s, naturalization rules have been liberalized in most European countries. Furthermore, the discretionary component to naturalization has decreased, although, in Europe, naturalization is a matter of right only in the Netherlands, Luxembourg, and Germany (Joppke, 2010, pp.45f). The shift in Germany is a case in point; until the early 1990s, when legislation was changed as an outcome of the compromise on asylum between Social Democrats and Christian Democrats, it was strongly emphasized that naturalization was a discretionary decision (Joppke, 1998b, pp.202f). In other countries, there is either more or less discretionary power to deny citizenship, even when conditions are fulfilled. Very wide discretionary powers are found in the case of Greece, where there is also no limitation to the time it may take to process a naturalization application (de Hart and van Oers, 2006, pp.328ff).

In Latin America, some states allow for quick processes of naturalization. In Argentina and Bolivia, two years of stay is required. Most states require a longer stay; in Chile, Colombia, and Mexico persons may apply after five years of residence. In some states, persons from Latin America and Spain can naturalize after a shorter period of stay. This is the case in Costa Rica, where persons from Central and South America and Spain may apply for citizenship after five years whereas other nationals have to wait seven years before being eligible. In Honduras, Central Americans may apply for citizenship after one year, Spaniards and Spanish-Americans may do so after two years, and others after 3 years. Some states, such as Mexico, require persons to have acquired knowledge of Spanish; Mexico also requires knowledge of history and society as well as a degree of integration in the national culture (US Government, 2001).

Several African countries allow for naturalization after five years of legal residence; this is the case in Gabon, Guinea, Madagascar, Mali, Morocco, Rwanda, South Africa, and Sudan. The lowest requirement regarding residence is Benin, where citizenship may be granted after only three years of residence. Several states require between seven and eight years of residence, for instance, the Democratic Republic of Congo, Kenya, Malawi, and Tanzania. However, a longer stay is required in several states: ten years is necessary in Angola, Burundi, Egypt, Mozambique, Namibia, Senegal, and Zambia. Some states require an even longer stay, such as 15 years in Nigeria and Chad, 20 years in Uganda, and 35 years in 
the Central African Republic (Manby, 2010, pp.64-72). The naturalization of spouses is facilitated in most states in Africa, and reforms undertaken over the last few decades have reduced the gender discrimination in this respect; nevertheless, several states still do not allow women to pass on citizenship to their non-citizen spouses (Manby, 2010, pp.45ff).

Most states in Africa include behavior and character requirements among the criteria for being granted citizenship; lack of criminal record as well as good conduct and morals are common formulations in legislation. Several states require persons to show sufficient income or other means of subsistence. Health requirements are also very common. Several states require prospective citizens to show they are assimilated or integrated into society, they have attachments to it, or that the new country is at the "centre of his/her principal interests,” as it is expressed in Cameroon's legislation (Manby, 2010, p.68). Among states that include criteria of assimilation and attachment are Algeria, Angola, Benin, Burundi, Cameroon, Ghana, Madagascar, Mali, Nigeria, and Togo (Manby, 2010, pp.68ff).

Closely related to criteria of integration are language requirements; knowledge of the language of the former colonial state, or local languages is required in, for instance, Benin, Kenya, Mozambique, and Tanzania. South African legislation requires persons to communicate in one of its eleven official languages. Most of the countries in North Africa, such as Egypt and Tunisia, require proficiency in Arabic. Some states have far-reaching language requirements; for example, Botswana and Ethiopia require persons to have knowledge in some of the local or national languages. Several states, such as Sudan, had requirements regarding language but removed these criteria in changes to citizenship legislation during recent decades (Manby, 2010, pp.64ff). Some states have racial, ethnic, or religious criteria for becoming a citizen. Liberia is at one end of the spectrum; 'non-Negroes' cannot become citizens in Liberia at all. Sierra Leone has far more restrictive rules for naturalization of people who are not 'Negroes'. In several countries in North Africa, such as Egypt, it is difficult to become a citizen if not of Arab origin or if not Muslim (Manby, 2010, pp.42ff). Aside from legal regulations, administrative and political processes in acquiring citizenship must be taken into account. In most states in Africa, the procedure for becoming a citizen is cumbersome and, in several states, involves decisions by government or parliament (Manby, 2010, pp.64ff).

The situation in states in Asia differs widely between states where there are several criteria for becoming a citizen to those where there are relatively few criteria. In 
Indonesia, South Korea, Thailand, and Vietnam, persons can naturalize after five years of lawful residence. Some states require a longer stay, for example, ten years in the Philippines. Several states—such as Cambodia, Indonesia, the Philippines, South Korea, and Thailandrequire an applicant to know the respective language and history. It is also a common criterion that persons must have means for their own subsistence. Some states require prospective citizens to make investments; this is the case in Bangladesh (US Government, 2001). In Japan, the status of permanent residence was created as an explicit alternative to immigrants becoming citizens (Surak, 2008); in the post-war construction of citizenship legislation, the model of transition from residence to citizenship had been implied but never implemented. With new legislation in 1990, this link was severed with the specific intention of avoiding a situation where immigrants would eventually become citizens. The citizenship legislation is itself not demanding, requiring five years of residence and 'upright conduct'. The latter is, however, interpreted in terms of assimilation, and authorities-besides demanding an extensive documentation of the applicant's home, family, and workplace-may also interview neighbors and co-workers to determine the moral character of the applicant. This process leads to a very limited number of naturalizations, and the status of permanent residence is considered by many to be more desirable than nationality (Surak, 2008, pp.562ff).

\subsection{Citizenship for Second Generation Immigrants}

Citizenship is acquired by birth on the basis of either the jus soli or the jus sanguinis principle. The latter principle creates problems for children of immigrants, but part of the liberalization of rules for immigrant incorporation over the past half century has been to facilitate acquisition of citizenship for second generation immigrants, either by incorporating jus soli in citizenship legislation or by having the right to choose the nationality of the state in which the persons are born (Goodman, 2010, pp.26ff; Joppke, 2010, chapter 2).

Germany is an example of a state that recently has included jus soli; as a result, Germany is a much-discussed case since this entailed a fundamental shift in its citizenship legislation. Several democratic immigration states include the possibility of opting for citizenship; when this is an uncomplicated process and not associated with conditions, it makes citizenship an entitlement for second-generation immigrants. However, there are some democratic immigration states that do not follow this pattern. For instance, Denmark recently 
abolished the optional acquisition of citizenship, and Japan has devised its citizenship legislation in ways that hinder the transition from permanent residence to citizenship (Ersböll, 2010; Surak, 2008).

Citizenship in Australia, Canada, and the US is based on jus soli. Australian citizenship was created through the Nationality and Citizenship Act in 1948 (entering into force in 1949); prior to this, UK laws applied and persons were British subjects. The jus soli principle was changed in 1986 so that only children with at least one parent being either a citizen or a permanent resident can acquire citizenship upon birth. However, children automatically acquire Australian nationality on their tenth birthday, irrespective of the legal status of their parents (Castles \& Vasta, 2004). Canadian citizenship also developed from UK nationality status; prior to the Canadian Citizenship Act of 1946, persons were British subjects (Bloemraad, 2006). The US has applied the jus soli principle for a long period of time. However, issues regarding immigration were not central to the establishment of this principle; instead, it was the confirmation after the end of slavery that every person born in the US is a citizen. This is specified in the Fourteenth Amendment of the Federal Constitution. In 1898, the US Supreme Court further specified the birthright citizenship principle by stipulating that it applies to persons born in the US when persons are either permanent residents or in the US on business (not diplomats). The question of whether the jus soli principle also applies to children born to undocumented migrants has been raised, and, even though the Supreme Court has not ruled on the issue, jus soli applies to this category of persons as well (Schuck, 1998, p.201).

British and French citizenship is based on the jus soli principle. The earlier regulation of British subjects was changed after the Second World War; the 1948 British Nationality Act set out who was a British citizen: persons living in the United Kingdom and persons living countries that were still colonies at the time. In the late 1960s, changes were undertaken regarding the immigration of former colonial subjects to reduce the number of persons immigrating to the UK. The current citizenship legislation was established in 1981, and it includes several categories: British citizen, British Overseas Territories' citizens, British Overseas citizens, British Nationals (Overseas), British subjects, and British protected persons. British citizenship is acquired at birth by children born to parents who are citizens or are settled in the UK (Groenendijk et al., 1998: 66; Layton-Henry, 2004). 
The jus soli principle has been applied in France since the late nineteenth century; for a long time, it was seen as embodying the republican ideal of citizenship. The core principle was the double jus soli rule, introduced in 1851, which stipulated that persons born in France to an alien father were to become citizens when reaching the age of maturity (Bertossi \& Hajjat, 2012, pp.4f). In the 1980s, however, anti-immigration agitation by Front National made the question of citizenship a major issue of conflict. The new centre-right government, which came into power in 1986, introduced several restrictive measures regarding immigration and moved ahead with changes to citizenship regulation; stressing the value of citizenship was among the arguments for change. The proposed reforms met with many protests from left-leaning parties and several associations, and the government backed down from them. A commission was appointed to discuss the issues; it proposed several changes which were taken up by the center-right government in 1993. Even though protests were voiced, they were not as focused as in the debates during 1986 (Hansen \& Koehler, 2005).

Revisions of central components of French citizenship legislation were undertaken in 1993, ending the automatic acquisition of citizenship at the age of maturity, modifying the double jus soli somewhat, and abolishing the extension of double jus soli to former French colonies (enacted in 1973). The new law entailed second generation immigrants having to express their willingness to become citizens between the ages of sixteen and twenty-three, and third generation immigrants were granted citizenship by birth only when parents had been living in France for at least five years (Bertossi \& Hajjat, 2012, pp.11ff; Hansen \& Koehler, 2005). When the left returned to office in 1997, it initiated changes to the 1993 law, re-instating persons born to foreign parents being citizens if they still lived in France at the age of maturity and had lived in France during their adolescence. In addition, the double jus soli rule was re-introduced for children of Algerian parents. The reform kept the part of the earlier law that focused on willingness to be a citizen by declaring this interest, but parents now can make this declaration with the child's consent between thirteen and sixteen years of age if the child has lived in France since the age of eight (Bertossi \& Hajjat, 2012, p.13).

Most other states in Europe base citizenship primarily on the jus sanguinis principle, although some states have more recently introduced jus soli elements into citizenship legislation. The most discussed example is Germany, which included the jus soli 
component by a legal reform in effect from 2000. The new citizenship law followed almost twenty years of debate on the need for reform, and some amendments in the early 1990s, to facilitate naturalization of non-citizens born in the country (cf. Green, 2012; Joppke, 1998b, chapter 6). Under the jus soli component, children of non-citizens are granted German citizenship when at least one parent is a permanent resident and has been residing in the country for eight years. Jus soli also gave the right for children born after 1990 to register for citizenship. In order to avoid multiple citizenships, persons are required to choose citizenship at the age of twenty-three. The inclusion of the jus soli component entailed a major shift in German policy, but the requirement that at least one parent is a permanent resident also created obstacles. Only about half of the children of non-citizens born in Germany get German citizenship at birth (Green, 2012; Hailbronner, 2010).

Other European states facilitate naturalization by giving a right to opt for citizenship. The Swedish Citizenship Act gives this option to children born to persons being permanent residents for five years (three years in cases of statelessness). Similar rules are found in several European countries, such as Belgium and the Netherlands (Groenendijk et al., 1998, p.26, 52). These rules were liberalized in the 1970s and 1980s, but there are several examples of restricting this access to citizenship over the last decade; for example, in Denmark, the option was made dependent on a lack of criminal record in 2000 and abolished altogether (except for other Nordic citizens) in 2003 (de Hart \& van Oers, 2006, pp.320ff). There are also some states in Europe where acquisition of citizenship by option has not been available, such as Austria (Groenendijk et al., 1998, p.69).

In Latin America, most states apply the jus soli principle, for example, Argentina, Chile, Brazil, Costa Rica, Ecuador, Honduras, Nicaragua, and Uruguay. Some states do not, such as Colombia, where children born to foreign nationals become citizens from birth if at least one of the parents has legal residence in the state (US Government, 2001).

Few states in Africa provide an explicit right to citizenship, and the status of stateless persons remains a problem. As Bronwen Manby put it in a study on citizenship laws in African states, "almost half of the African countries have citizenship laws that practically guarantee that some children born on their territory will be stateless” (Manby, 2010, p.37). Only sixteen states have laws that follow the 1961 Convention on the Reduction of Statelessness. The South African constitution recognizes a constitutional right to citizenship 
for children, and the Ethiopian constitution does likewise; however, the Ethiopian nationality legislation does not follow this constitutional regulation. Kenya recently adopted new legislation concerning the rights of the child that both follows the Convention on the Rights of the Child and recognizes a right to nationality. Countries following the jus soli principle have the strongest protection against statelessness, but few states in Africa (Chad, Lesotho, and Tanzania) base their citizenship legislation primarily on jus soli. Several states either allow for children to claim nationality from birth if they are still residing in the country when becoming adults or allow children to have nationality from birth if at least one of their parents is a citizen. The latter kind of regulations is found in Benin, Cameroon, Chad, Ghana, Guinea, Mozambique, Rwanda, Senegal, Tunisia, Uganda, and Zambia. Namibia and South Africa grant citizenship to children born by persons having long-term residence (Manby, 2010, pp.34ff)

Japan is an example of a democratic state where transition from residency to citizenship, common in democratic immigration states, does not apply. This also entails that, besides the naturalization process, there is no special option for citizenship among second generation immigrants (Surak, 2008).

\section{Multiple Citizenships}

Multiple citizenships, or dual citizenship ${ }^{2}$, were, for a long time, seen as a problem by states; security risks, dual voting rights, consular issues, and lack of loyalty were among the issues discussed. It was generally argued that dual citizenship might compromise one's allegiance to the state. International and regional conventions on citizenship reflected this concern. However, the stance towards multiple citizenships has, at least partly, shifted during recent decades, and the Council of Europe convention concerning nationality from 1997 is neutral on the issue. Today, an increasing number of states recognize multiple citizenships in principle (Blatter et al., 2012; Faist, 2007; 2008; Howard, 2005; Sejersen, 2008).

In a study from 2008, Tanja Sejersen showed that out of the 115 countries examined, about half of them allow for multiple citizenships. Asian states do so to a lower

\footnotetext{
${ }^{2}$ We will use the terms multiple citizenships and dual citizenship interchangeably. It is rather common to use the term dual citizenship, but it is perhaps more proper to use the term multiple citizenships because states cannot restrict it to citizenship in only two states.
} 
degree than states in the Americas, Europe, and Africa. The number of states that de facto tolerate multiple citizenships is significantly higher than those that legally recognize a right to multiple citizenships (Sejersen, 2008). When the latter category is included, about 60 percent of states in the world allow for dual citizenship in some form. Joachim Blatter et al. classify states into several categories: 73 states in the world fully acknowledge dual citizenship, 14 states do so de facto or on the basis of treaties, 24 states show very limited acceptance of dual citizenship, and 53 states do not allow for dual citizenship. For another 25 countries, studies have not produced any consistent results (Blatter et al., 2012, pp.9f).

When taking into account the different ways in which persons may become de facto dual or multiple citizens, avoiding dual citizenship is not the overriding concern it once was. International norms, in particular avoiding statelessness, take precedence over avoiding dual citizenship. Fairness and democratic considerations also play a role. The latter is shown in cases where some persons do not have to revoke their previous citizenship because it is either impossible or very costly and difficult. There are thus several reasons for the trend towards increasing acceptance of multiple citizenships. De facto tolerance, the importance of considerations - such as fairness, democracy, and inclusion-in immigration states, and the importance of norms like that of avoiding statelessness are important factors (Faist \& Kivisto 2008). However, facilitating immigration and retaining connections to citizens who settle and naturalize in other countries are also very important reasons for recognizing dual citizenship. The attempt to retain ties with citizens is a particularly prominent objective; states that traditionally have not been very keen on developing a diaspora, such as countries in northwestern Europe, now engage in these practices by allowing for multiple citizenships (de Hart, 2007).

Australia, Canada, and the US allow for multiple citizenships. Becoming a US citizen requires citizens to take an oath of allegiance that entails renouncing other citizenships, and the non-acceptance of dual nationality was upheld for a long time. President Theodore Roosevelt declared, in the early twentieth century, that dual citizenship is a "selfevident absurdity” (cited in Spiro, 1997, p.1430). Even though dual citizenship has not been fully embraced as an idea of special value, multiple nationalities have become tolerated, as upheld by the US Supreme Court (Jones-Correa, 2001, pp.1012f). Well into the 1960s, US citizens could lose their citizenship either when marrying a foreigner or when voting in elections in another country, but this practice ended when the Supreme Court declared it 
unconstitutional. The Court ruled that Congress had no power to take away citizenship unless a person voluntarily relinquishes it (Schuck, 1998, pp.167ff). Australia and Canada also allow dual citizenship (Blatter et al., 2012).

In Europe, British nationality laws allowed for multiple citizenships of immigrants and emigrants. The same has applied in France since 1973. Sweden has recognized dual citizenship since 2001; aside from de facto toleration, two types of arguments were important in the Swedish debate. One argument focused on how dual nationality may contribute to immigrant integration. This was the dominant argument in the 1980s, when center-right parties argued against dual nationality. The other argument focused on the possibilities for emigrants from Sweden to retain connections to Sweden when naturalizing in another country. This kind of argument became prominent in the 1990s and was important in changing several center-right parties' views regarding dual citizenship (Gustafsson, 2002; Spång, 2007).

In several other European countries, dual citizenship is not acknowledged. Examples include Austria, Denmark, Germany, Poland, the Czech Republic, and the Baltic states (Howard, 2005). In several states, discussions on dual citizenship have been heated. Allowing for dual citizenship was part of the citizenship reform proposed by the Social Democrats and the Greens in Germany during the late 1990s; however, due to opposition, especially by the CDU/CSU (which organized a petition campaign in the regional election of Hesse in 1999), the governing red-green coalition lost the majority in the Bundesrat and had to enter into negotiations with the Liberals. The government agreed with the Liberals on the jus soli reform but not on allowing dual citizenship (Gerdes, Faist \& Rieple, 2007). The principle of avoiding dual citizenship does not mean, however, that it is not de facto tolerated. European states increasingly came to tolerate dual citizenship from the 1970s onwards. Between 40-50 percent of immigrants naturalizing in Germany since 2000 are de facto dual citizens, and the percentage is approximately the same in Denmark (Ersböll, 2010; Green, 2012).

Some European states allow for dual citizenship only for those who are citizens from birth. Traditionally, this has been a common policy in emigration states in order to retain ties with persons emigrating and settling in other countries (Gorny, Grzymala-Kazlowska, Korys \& Weinar, 2007). A somewhat new trend is that this focus is found also in immigration states. In the Netherlands, the requirement of renouncing citizenship when naturalizing was 
abolished in 1992 and then re-instated in 1997. With the new citizenship law coming into force in 2003, the possibility of dual citizenship was opened up-but for Dutch-born citizens only. The 1992 decision allowing for dual citizenship can be seen as an outcome of the process of facilitating naturalization that had been a central part of Dutch policy for some time. The re-instating of the principle was largely an outcome of a shift in the public debate on citizenship; instead of looking at citizenship as part of the integration process, it was increasingly seen as the end-point or crowning of successful integration (de Hart, 2007). Some scholars, like Joppke, view the distinction between citizens and non-citizens as well as the recognition of dual citizenship for native-born citizens only as an example of the reethnicizing of citizenship laws (Joppke, 2010, pp.63ff).

Several Latin American and Caribbean countries recognize multiple nationalities. Uruguay has done so since 1919, and several of the states in the Caribbean have acknowledged multiple nationalities since independence. However, in most Latin American countries, recognition of multiple citizenships is of more recent origin, for example, in Colombia (1991), the Dominican Republic (1994), Costa Rica (1995), Ecuador (1995), Brazil (1996), and Mexico (1998). Some states—such as Argentina, Chile, Guatemala, Nicaragua and Paraguay — only recognize dual nationality on the basis of treaties (Jones-Correa, 2001, pp.999). In most of these states, dual nationals retain their voting rights in the home country, and several states allow for voting at consulates abroad, whereas others do not (for instance, Mexico and the Dominican Republic) (Jones-Correa, 2001, pp.1010f).

Emigrant groups have been important in this trend towards recognizing dual nationality. Emigrant groups, especially in the US, were a driving force in Colombia, Ecuador, the Dominican Republic, and Mexico. In particular, the success of Colombian groups in pressing for dual nationality and voting rights were important for Ecuadorian and Dominican groups to engage in similar attempts to convince their respective parliaments and presidential candidates of their case. In Mexico, competition for support between parties played an important role; the opposition rallied in western and southern US for support, promising dual nationality, and the then governing Partido Revolucionario Institucional (PRI) also joined in. It is clear that campaign fund raising — and, more generally, remittances-are important reasons for politicians in Latin American countries to favor dual nationality (JonesCorrea, 2001, pp.1001ff). 
An increasing number of African countries also recognize multiple citizenships: thirty states now allow for multiple citizenships (Manby, 2010, pp.58ff; Whitaker, 2011). Among them are states like Senegal, which has recognized dual citizenship since independence, and states like Ghana and Kenya, which have begun to recognize it more recently. Senegal allows for multiple citizenships and recognizes voting rights as well as the right to hold office for dual citizens. The issue has not become politicized to the degree it has in several other countries (Whitaker, 2011, pp.765ff), such as in Ghana, where dual nationality was recognized during the mid-1990s through amendments of the 1992 constitution, but provisions of how to implement dual nationality were not given until the adoption of a new citizenship law (entering into effect in 2002). The issue has been politicized, with the question of emigrants' right to vote being particularly controversial. The traditional ruling party, the National Democratic Congress (currently in government), has opposed allowing emigrants the right to vote, whereas the opposition New Patriotic Party (in government between 2000 and 2008), has been in favor of it (Whitaker, 2011, pp.769ff).

Kenya belongs to the states that have very recently recognized dual nationality, by a change of the constitution in 2010. Unlike in Senegal, security issues have been important in Kenya, where, due to the large Somali population residing in the country, there are widespread worries regarding allowing dual nationality for immigrants. Kenyan legislation, therefore, allows dual nationality only among Kenyan emigrants (Whitaker, 2011, p.773). Several countries in Africa do not allow multiple citizenships, for example, Algeria, Botswana, Cameroon, Ethiopia, Liberia, Malawi, Tanzania, and Tunisia. Some allow dual citizenship only in some cases, for instance, when women acquire the citizenship of their spouse when marrying a foreigner; this is the case in the Ivory Coast and in Zambia, among others (Manby, 2010, p.63).

In Asia, some states, such as Bangladesh, allow dual citizenship in some form, whereas several states — such as China, Indonesia, and Japan-do not allow or tolerate multiple citizenships. Some states, like Pakistan, allow for dual citizenship only on the basis of treaties with other states. For several states, existing studies give conflicting answers to the extent to which dual nationality is allowed or tolerated; this is the case with India, South Korea, Thailand, and Vietnam (Blatter et al., 2012). 


\section{Explaining Differences in Incorporation Policies}

The differences between states regarding laws and policies of immigrant incorporation depend on several factors, such as the type of political system, commitment to human rights, nationhood conceptions, regional integration, colonialism, and other historical ties. When considering the incorporation regime, it is important to understand not only that the policies may be explained by several factors but also that access to rights and citizenship for immigrants may have little to do with migration. As noted above, the jus soli principle in US citizenship legislation does not stem from considerations regarding immigration but from an attempt to uphold equal treatment of African Americans after the abolishment of slavery (Joppke, 2010, pp.37f).

\subsection{Democracy}

Democratic immigration states with strong commitments to human rights usually grant easier access to a secure legal status and to rights due to the inbuilt inclusion logic of democracies; the claim to political inclusion arises from persons being de facto citizens, by the needs to, for example, abide by the law and pay taxes. The democratic presumption is that the addresses of law need also to be authors of law (cf. Benhabib, 2004; Habermas, 1992). Several scholars have stressed the importance of principles and values central in constitutional democracies when explaining both the extension of rights to non-citizens and the creation of a more secure legal status for immigrants (Freeman, 1994; 1998; Joppke, 2010). Patrick Weil has stressed the entrenchment of constitutional democratic values as an important factor-together with a high number of permanent residents and the absence of unresolved border issues-in explaining liberalization of citizenship legislation in democratic immigration states (Weil, 2001).

Several scholars have investigated more specific dimensions to the connection between democracy and expansion of immigrants' rights. Gary Freeman has stressed the role of client politics; whereas benefits of immigration are specific (for instance, benefits for employers and for immigrants organizing in associations to influence politics), the potential costs are diffuse (Freeman, 1994). Client politics seems particularly suitable to explain developments in the US, but less so in Europe. Joppke, for instance, has argued that in European states courts and, partly, state administrations explain why there has been a 
development towards increasing equality between long-term residents and citizens (Joppke, 1998a). However, other scholars have emphasized that Joppke's focus on courts is exaggerated as regards several countries in Europe. Much of the expansion of access to rights for non-citizens are better explained by the praxis setting of bureaucracies in several European states. Moreover, in some states, the expansion of rights is the outcome of politically driven processes in which, for instance, social democratic parties played an important role. The expansion of rights has been an outcome of a politically driven process together with praxis setting by bureaucracies operating in an area of little political conflict, as seen through the endorsement of integration polices and citizenship laws in states like the Netherlands and Sweden from the 1960s to the 1980s (Bonjour, 2011; Hammar, 1990). Besides immigration being a low rather than high political issue, what Freeman called 'the anti-populist norm' also played a role in explaining liberalization in several democracies. The latter norm may be less strong today; the increasing strength of right-wing populist parties in Europe, and the difficulties established parties face in handling right-wing populist parties, make it more tempting for established political parties and other actors to also play the immigrant card (Freeman, 1994; Guiraudon, 1998).

Much of the discussion concerning both the connection between principles and values in constitutional democracy and the extension of status and rights to immigrants have focused on classical immigration states and states in Europe. When looking at other democratic states, however, this connection is not as obvious; the creation of obstacles to naturalization in Japan demonstrates this. Furthermore, in the Japanese case, the steps taken to create a more secure legal position for immigrants do not stem from constitutional democracy as much as from the impact of international human rights and from problem-solving perspectives (Surak 2008).

Democracy matters also when trying to explain the acceptance of dual nationality, even though the situation in this regard is far from clear-cut (as shown by several examples in Europe). Beth Whitaker argues that democratization has been very important in explaining the turn towards acceptance of multiple citizenships in Africa, as the process towards democracy both makes questions of voting rights central and allows for diaspora groups to engage in politics. The agitation of diaspora groups in pressing for changes that allow for dual nationality and voting rights for emigrants are important factors in some states, such as Ghana, where diaspora groups in Canada and the UK played an important role. 
Furthermore, there is also a narrower self-interest among politicians to allow for voting rights since diaspora groups are important for raising funds to participate in elections (Whitaker, 2011, pp.777ff). As discussed above, the same pattern is found in several Latin American states.

The connection between democracy and protection of rights for immigrants is not straightforward. The risks of majority tyranny have been part of debates on democracy for a long time, and immigration and citizenship policies are examples in which this risk is pertinent. Several categories of immigrants lack access to political rights and often have an insecure legal status. Those who have a more secure status and enjoy similar political rights as citizens may lack the necessary resources to be able to participate in politics. Furthermore, there are conceptual reasons for majority tyranny being a particular risk for immigrants. This is because of the conceptual connection between democracy and demos circumscribed in place and time, which often leads to restricting immigration for reasons including the realization of a democratic order and a welfare state as well as several other public goods (Benhabib, 2004; Gibney, 2004).

Another reason for the less than obvious connection between democracy and extending immigrants' rights concerns the role of populist argumentation in democracies (Guiraudon, 1998). The mobilization against immigrants in several democratic immigration states over recent decades is clearly important for explaining more restrictive immigration and citizenship policies. For example, in Denmark, the Danish People’s Party has played a central role, first by making immigration one of the most important political questions and then by influencing legislation because of its key position in support of center-right governments (Ersböll, 2010). Virgine Guiraudon has emphasized the interrelation between the electoral calculus of politicians, media, and public opinion in this regard. Media coverage of problems relating to immigration makes it potentially electorally beneficial to play-on and/or exploit xenophobic and anti-immigrant feelings (Guiraudon, 1998).

Democracy, then, plays an ambivalent role with regard to immigrants' rights and opportunities. On the one hand, the democratic presumption of being able to participate politically when being a de facto citizen point to the importance of facilitating both political participation of non-citizens and easy access to citizenship. This in-built presumption in democracy also explains, several scholars argue, the trend towards liberalization seen in many immigration states since the Second World War. However, on the other side of the relation 
between democracy and immigrants' rights, xenophobic and anti-immigration sentiments are not only easily articulated in democracies, but they also have a bearing on the electoral calculus.

\subsection{Human Rights}

In the general discussion of democracy and immigrants' rights, several scholars have argued that it is not so much political participation but the rights component of modern democracy that matters. Scholars have stressed that the emerging regional and global human rights regimes after the Second World War have led to an increasing emphasis of rights being based on residence (jus domicilii) rather than on citizenship, especially in Europe and Latin America. A cornerstone of the international human rights regime is that enjoying rights, with some exceptions like the right to vote, should not be based on citizenship; several scholars have argued that the impact of this norm is important in explaining the untying of access to legal status and rights from access to citizenship (Jacobson, 1996; Soysal, 1994; Benhabib, 1994).

The importance of human rights in explaining changes to citizenship legislation led, during the 1990s, to a debate regarding post-national citizenship. Yasemin Soysal argued in her book Limits of Citizenship (1994) that, when analyzing the incorporation of immigrants, one needs to take social rights as the starting point (as opposed to civil and political rights in T.H. Marshall's scheme); furthermore, Soysal argued one should consider the impact of international and regional human rights conventions. Soysal (1994) claimed that the status and rights of immigrants are increasingly determined by what human rights stipulate. Soysal's and others' arguments on post-national citizenship (cf. Bauböck, 1994) led to much debate, with several scholars criticizing this interpretation. These scholars argued it is not so much the impact of human rights that matters but the democratic traditions and the integration regimes of specific states. With regard to Germany, Joppke (1998b, chapter 6) has argued that immigration does not render national citizenship obsolete but shows its continued importance. The introduction of jus soli elements matters significantly for immigrant incorporation, but this is not understandable from a post-national perspective (Joppke, 1998b, p.274). Moreover, in spite of the increasing importance of human rights, citizenship still matters for access to several types of rights, and some scholars argue the importance of citizenship has increased 
over the past decade (Goldston 2006). Koopmans et al. (2012) have recently shown that liberalization in access to rights continued in several European states until 2002, after when it has stagnated and, to some extent, reversed. It has also been suggested by scholars that we are currently witnessing an increasing importance placed on citizenship when regulating access to rights. States increasingly use citizenship to carve out important exceptions to the enjoyment of human rights (Goldston, 2006).

\subsection{Nationhood}

Another factor often said to explain differences between incorporation regimes is the conception of nationhood that underlies citizenship legislation. It has been common to differentiate between ethno-cultural and civic-republican conceptions of nationhood. The latter are based on citizens sharing political values and ideas, such as equality and freedom, whereas the former depend on shared belonging in terms of, for example, ethnicity, language, and religion. A minor classic is Rogers Brubaker's (1992) study on the conception of nationhood and citizenship in Germany and France.

Brubaker argued that the more restrictive approach to citizenship in Germany could be explained by the country's stronger emphasis on ethno-cultural conception when compared to France. Brubaker explained the more open approach in France in terms of the civic-republican conception of the nation (Brubaker, 1992). Brubaker's study generated several similar studies of different states, and conceptions of nationhood have figured prominently in studies of naturalization rules (cf. Weil, 2001), citizenship by socialization (cf. Koopmans et al., 2005), and dual citizenship (cf. Faist, 2007). However, in several of these studies, the initial assumption of the importance of nationhood conceptions was revised. In studies on dual citizenship in several European countries, nationhood conceptions were shown to be not important in explaining acceptance of dual nationality. Instead, other factors, including a focus on societal integration, proved to be more important in explaining outcomes in different states (cf. Faist, 2007). Accordingly, several scholars have argued the connection between nationhood and citizenship is overstated; for instance, they claim it is difficult to understand how the introduction of jus soli in German citizenship legislation in 2000 could be explained. It has been claimed that the division of Germany was more important in explaining why West Germany retained citizenship legislation from 1913. The old legislation served as 
an instrument both to undermine the legitimacy of East German citizenship legislation and to hold the door open for reunification. After unification, Germany embarked also on a substantial overhaul of its citizenship legislation (Gerdes, Faist \& Rieple, 2007, pp.49f; Joppke, 1998b, chapter 6).

Comparing France and the US also calls into question the underlying rationale of Brubaker’s study (cf. Joppke, 1998b). Both France and the US are traditionally considered examples of states having a civic-republican conception of the nation; however, while the state has played a central role for immigrant integration in France, this has not been the case in the US. This means also that the understanding of what constitutes the republican dimension of citizenship differs; state institutions are responsible for fostering the assimilation of immigrants into the French republican model in ways that they are not in the US, where voluntary associations and markets are more important. The differences in understanding the division between church and state also demonstrate substantial differences to civic-republican conceptions in the two states. In the US, this has largely entailed neutrality of the state, but in France it has, in the tradition of laïcité, entailed the combating of religion in the public sphere. With regard to religion, in Germany-with its ethno-cultural model of the nation, according to Brubaker-there has been more tolerance than in France. The controversy over headscarves in Germany resembles that in France when looking at some aspects of public debate, but the positions of political institutions and courts are quite different (cf. Benhabib, 2002).

The assumption that civic-republican conceptions of nationhood are less ensnared in exclusion has also been questioned. Scholars have pointed to the exclusionary logic implied in civic-republican conceptions of nationhood, for instance, when immigrants are seen as not sharing the values of equality, freedom, democracy, and the like that are embodied in the civic conception of the nation (cf. Davidson, 1999). The same claim lies behind Joppke's argument that the major form of exclusion in democratic immigration states today is to be understood in terms of a particular universalism. The new demands being placed on immigrants reflect less the reassertion of specific ethnic and cultural traditions than the suspicion that immigrants do not endorse values central to liberal democracy (Joppke, 2010, pp.137ff).

The character of the integration policy is partly connected to those nationhood understandings. Several democratic immigration states, such as Canada and Australia, adopted multicultural integration policies during the 1970s. It has been commonly argued that 
multicultural integration policies are conducive for immigrant incorporation because such policies facilitate the formation of associations, inclusion in politics, and easier access to rights and citizenship. In her study of immigrants in Boston and Toronto, Irene Bloemraad (2006) argued that the more successful political inclusion of immigrants in Toronto was largely due to Canadian multicultural policy; however, the conclusions that multiculturalism facilitates political inclusion and participation have, to some extent, been revised over the past decade. Koopmans et al. (2005) noted that immigrant political participation was higher than expected in France and lower than expected in the Netherlands, arguing that access to rights that allow for claims-making in the public, when also tied to assimilation and civic-republican ideals (France), fostered participation in politics. Similarly, multicultural integration policies foster such engagement, but the relation between participation and multiculturalism seems to be curvilinear. Multiculturalism tends to give rise to an inward orientation of groups, discouraging participation in the broader public sphere (Koopmans et al., 2005, chapters 3-4).

Questions concerning the openness of a national citizenship regime to the international community are related both to nationhood understanding and to integration policies. Behind several studies both of transnationalism and of cosmopolitanism lies an assumption that ties that transcend national borders are more encouraged in some states than in others. Traditionally, several emigration states have been interested in developing and sustaining ties to citizens in other countries. Recent studies have shown states with a more internationally oriented state identity are more likely to acknowledge dual citizenship than other states, whereas states with a largely national orientation and that adopt assimilationist policies are less likely to adopt dual nationality (Dahlin \& Hironaka, 2008).

\subsection{Colonial Background and Other Historical Ties}

The colonial background is important when wanting to explain citizenship legislation. Aside from the impact manifested in several post-colonial states adopting citizenship legislation similar to that their respective colonial power, the long- and short-term effects of colonial policy is evident in aspects such as access to rights and naturalization. The colonial background is important for creating special ties between states, such as between Spain and several countries in Latin America, and in the British Commonwealth. Several states in Latin America have treaties with Spain allowing for dual nationality (Rubio Marin \& Sobrino, 
2010). In the British Commonwealth, the abolishment of the status as British subject in the late 1940s and the adopting of citizenship laws in countries becoming independent led to a change in access to rights in Great Britain. The Commonwealth status still has some importance, but the main impact on citizenship issues in former British colonies lies in British legislation shaping the laws and policies of former colonies (Manby 2010).

The impact of racial and ethnic categories introduced by colonial powers is shown in several states in Africa and Asia. In some African states, access to citizenship by descent is limited to members of groups whose ancestral origins are within the specific state or of African origin (Manby, 2010, pp.42ff). To some extent, this is a reversal of policies adopted during colonial times, when indigenous peoples were subjects of the colonial power, did not have access to rights, and were governed by customary law. This not only led to substantial problems for the post-colonial state in Africa in terms of overcoming the differences between civil law and customary law (Mamdani, 1996), but it also had consequences with regard to persons who were not seen as belonging to the nation that had gained independence. Following independence, creating citizenship laws that confirmed the people becoming independent also created problems for groups seen as non-indigenous. Even in cases where these groups had been settled for a long time, they were excluded from citizenship (Akyeampong, 2006). In some Asian states, such as Malaysia and Indonesia, the British fostered the attitude that the Chinese population was non-indigenous, and the Dutch pursued a similar policy in Indonesia. Despite an ambition to include all Indonesians after independence, the impact of the colonial differentiation was also obvious, for instance, in privileging 'natives' over Chinese in economic policies. Under Suharto's rule, there were explicit attempts both to obliterate Chinese-ness, for instance, by banning Chinese publications and schools, and to promote assimilation, which encouraged conversion to Islam. To some extent, the distinctions between 'native' and Chinese populations, important in the early decades after independence, have - in Indonesia and, in particular, in Malaysia — been replaced with increasing differentiation vis-à-vis new immigrant groups coming as labor immigrants from neighboring countries (Aguilar, 1999).

\subsection{State- and Nation-Building}


Citizenship legislation figures prominently in state- and nation-building projects, in which defining who is a citizen and who belongs to the nation is very important. However, the process of defining citizens may entail excluding people belonging to minorities, as evidenced in the previous discussion on persons of Chinese descent in some South Asian countries.

Another example is the exclusion of Russians at the time of independence (around 1990) of the Baltic states. New citizenship laws were setup on the basis of rules and regulations stemming from the inter-war period. Upon independence in the Baltic States, many Russians were not granted citizenship (Groenendijk et al., 1998, pp.72f). Soviet rule entailed attempts of russification, and, in order to mark the newly won independence, Estonia and Latvia based their new citizenship legislation on their respective situations before being annexed by the Soviet Union. Those who could not show their relation to persons being citizens before 1940 were not granted citizenship; instead, they were required to naturalize. As a result, almost half a million persons in Estonia became aliens (Groenendijk et al., 1998, p.72). The naturalization requirements included knowledge both of the Estonian language and on the Estonian constitution. This excluded several parts of the Russian-speaking population, leading to many debates concerning the problems with such legislation from a democratic perspective. Later, citizenship legislation was amended in order to try to ameliorate the situation, but many Russian descendents in Estonia and Latvia remain non-citizens (Ziemele, 2005).

\subsection{Regional Integration}

Regional integration is also a factor in explaining incorporation regimes. Besides the common practices of states imitating others when constructing citizenship legislation, several states cooperate on a more or less stable basis in developing citizenship laws. Until the last decade, when they parted company on several issues of citizenship, the Nordic states developed common citizenship laws by joint committees (cf. Sandesjö \& Björk 2005).

More recent examples of the impact of regional integration are found in the EU, in which the EC court has significantly extended the rights that accompany persons moving and settling in another member state. Scholars point to the court's importance in relation to to protecting rights for member states' citizens when migrating to another member state (cf. Weiler \& Wind, 2003). The question of third country nationals was, for a long time, a matter 
of debate, but recent EU directives have strengthened their access to rights. As seen in previous sections about reforms regarding long-term residents, EU legislation has played an important role in national reforms (Niessen \& Huddleston, 2009).

\section{Political Inclusion: Voting and other Forms of Participation}

Political participation involves several forms of engaging in politics, such as voting and engagement in political parties and associations, taking part in public debate, and civil disobedience. Regarding forms of participation, it has been common to distinguish between conventional and non-conventional forms: conventional (institutional) forms of participation include voting and participation in political parties and organizations, whereas nonconventional (non-institutional) methods include engaging in boycotts and civil disobedience acts. It is also common to distinguish between low and high costs of participation: voting is a low cost activity and contacts with politicians, whereas working in a party or organization are high cost activities (Rooij, 2012).

Studies of political participation have directed attention to several factors that determine the extent to which individuals participate. Verba et al. (1995, part 3) argued that resources, engagement, and recruitment affect the level of participation. Among resources are time, money, and civic skills, such as communication and organizational abilities. When addressing immigrant participation, citizenship may be an important resource to complement those more traditionally focused upon in studies of voting and in other forms of political participation (Just \& Anderson, 2012). Engagement includes such things as political interest and sense of civic duty, and recruitment refers to people often needing to be asked to participate (Verba et al., 1995, part 3); these factors are important when looking at immigrant participation. Studies have shown that, in particular, recruitment matters when wanting to explain levels of participation and modes and interlinking of different forms of participation (Rooij, 2012).

Another important issue in studies of political participation concerns how the political system affects levels of participation, as well as the kind of participation persons engage in. Studies have shown, depending on the degree of openness of a political system, participation will take different forms. In relatively closed political systems, more unconventional methods are likely to be used, whereas the opposite will be the case in 
relatively more open political systems. These dimensions are important when looking at immigrant participation (Ireland, 1989). However, the characteristics of the citizenship and integration regimes are even more important with regard to immigrants. Koopmans et al. (2005) compared immigrant participation in several west European states, showing there are significant differences in this respect.

Restrictions of immigrants' opportunities to take part in politics have been removed in several democratic states, even though most states reserve the right to vote for citizens. Nevertheless, changes undertaken over recent decades have given access to voting rights on local and regional levels to non-citizens in several countries, as discussed above (Martiniello, 2006). We begin this section by considering voting among non-citizens and voting among naturalized citizens, before moving on to consider other types of participation. Whereas most of those who participate as naturalized citizens or as long-term residents have access to political rights and a secure legal status, this is not the case with irregular migrants. Nonetheless, even irregular migrants engage in some political action, which we consider at the end of this section.

Studies of participation among citizens and non-citizens show non-citizens participate in politics less than citizens, both citizens from birth and by naturalization (Just \& Anderson, 2012; Maxwell, 2010). In the first election (1976) when non-citizens had the right to vote in local and regional elections in Sweden, about 60 percent took part. At the time, it was thought that the participation rate would most likely increase when more people got accustomed to having the right to vote. However, the turnout has decreased over time and is today below 40 percent (Bevelander \& Pendakur, 2011b; Hammar, 1990, chapter 9; Bäck \& Soininen, 1998). Similar differences between voting turnout of non-citizens and citizens are found in other countries that recognize voting rights for non-citizens on the local level, but the decline in some countries, such as Denmark, has been less pronounced than in other countries, such as Sweden (Togeby, 1999)

The differences between citizens and non-citizens are to be expected for two main reasons: because citizenship gives access to rights—in particular, the right to vote-and because acquiring citizenship is possible only after staying a number of years in a state, which generally affects one's propensity to participate. In discussions on the socialization effect, some scholars emphasize the more traditional view, namely, that political socialization is a long process whereby persons acquire adequate knowledge and an interest to take part in 
politics during adolescence and as young adults; others argue there is also a significant shaping of the propensity to participate that stems from exposure to the political system. The latter is greater, ceteris paribus, where persons have resided for a long period in the state (Just \& Anderson, 2012; White et al., 2008).

Regarding those who are citizens, there are fewer differences between persons with or without immigrant background. Studies show there are differences only with respect to voting - not in other respects. In a US study, naturalized citizens vote to a lesser extent than US-born citizens (Bass and Casper, 1999). In a study using data from the European Social Survey (2002/2003), with regard to contacting politicians, working in political parties, signing petitions, and civil disobedience, there were no differences between ethnic minorities and majorities (Sandovici \& Listhaug, 2010). Studies of participation in Australia show similar patterns between immigrants and citizens from birth; in most cases of participation, there are no major differences between those born in Australia and those born overseas. There are some differences regarding voting between those born overseas in English speaking countries and those from non-English speaking countries, but, with respect to other forms of participation, persons from non-English speaking countries do not take part in politics less than others (Bean, 2012).

Standing for office is also a central dimension of electoral politics. In general, proportionally fewer immigrants are elected to political office than who take part in voting. In Germany, the proportion of Turkish immigrants elected to city councils and state parliaments is between 0.5 to 1 percent. In the Netherlands, immigrant representation is higher in some municipalities, such as Amsterdam and Rotterdam. The same applies in the UK and the US, whereas in France there are fewer immigrants elected to the local levels in big immigration cities (Alba \& Foner, 2009).

Regarding which parties immigrants vote for, several studies show that persons with an immigrant background tend to vote to the left. In the UK, close to 90 percent of Asians and Afro-Caribbeans voted for Labor in 1979, but this declined to about 60 percent by the end of the 1980s (Anwar, 2001).

Among factors that determine voter turnout rates, money, education, civic status, age, time, civic skills, and access to networks (recruitment) matter in explaining differences between groups. This goes for immigrants, as well, but there are also specific 
factors that affect immigrant turnout besides these factors, such as length of residence, length of citizenship, and geographical location. Studies of voting in France in the early 2000s showed there was a significant neighborhood effect in the propensity to vote (Maxwell, 2010). Mobilization also matters in explaining differences between groups as well as between cities and regions within the same state. In a study of the 1997 municipality election in Denmark, Lise Togeby (1999) argued the higher participation rate in the city of Århus compared to Copenhagen could be explained by higher levels of mobilization in Århus.

Besides voting, there are several other important forms of participation. One type of participation connected closely to elections is membership and participation in parties, associations, and interest organizations. Several studies point to lower levels of participation in these associations and organizations among immigrants in most democratic immigration states, but these levels differ both between countries and between different immigrant groups. Togeby (2004) has shown that in Denmark, Turks participate in unions and in ethnic organizations to a significantly higher degree than persons from the former Yugoslavia; for the Turks, this participation leads to more extensive participation in elections. These differences suggest there are differences between associations and organizations: some contribute to building capabilities that further participation, whereas others do not (Togeby, 2004). Studies in other countries confirm this, for example, the study on participation in ethnic associations in the Netherlands (van Londen et al., 2007). Findings from research on immigrant associations in Sweden suggest the idea of ethnic associations contributing to higher levels of involvement in political processes may be overstated. Research has shown that membership in ethnic associations does not contribute to political participation in the same manner that being a member of associations in general does. However, the reason for this may be less the inward orientation of ethnic and religious associations and more that the civic skills acquired by members in ethnic associations are not translated to other forms of political participation due to a lack of recruitment networks (Strömblad \& Adman, 2009).

Participation in public debate is yet another form of participation. Koopmans et al. (2005, pp. 78ff) showed, in their comparison of five European states, migrants and minorities are more visible in the public debate and discourse in the UK than in Germany or Switzerland, with France and the Netherlands being in between. Anti-racist and pro-minority groups are more visible in public discourse in France than in the other countries. In the same study, it was also shown there are significant differences in the issues raised in the public 
debate concerning immigration. The dominant theme in Switzerland concerns immigration and asylum policy, whereas non-institutionalized racism and xenophobia are major issues in France and Germany. Discrimination and unequal treatment are major topics in the UK. Homeland oriented politics are very important in Germany and Switzerland, but they play a marginal role in France and the UK (Koopmans et al., 2005, pp.88ff and 127ff).

Participation in demonstrations and in other non-institutionalized and, especially, non-conventional forms of politics, such as civil disobedience, are also important. There are several examples of civil disobedience acts involving immigrants, but, overall, this remains a rather marginal phenomenon. Koopmans et al. (2005, pp. 135ff) showed demonstrations and violent protests play a more important role in Germany and Switzerland than in the Netherlands and the UK, where public statements make up the bulk of actions taken. Demonstrations are an important action repertoire in France, but violent protests are not.

Institutionalized consultation with associations has been common in several democratic immigration states. Immigrant associations and ethnic and religious associations have been included in policy processes (Entzinger, 1997). The extent to which such consultations take place varies between states: They have been less common in France, which lacks this tradition, than in Canada, Germany, the Netherlands, the Scandinavian countries, the UK, and the US. There has also been a change over time; many consultative bodies involving immigrant associations were set up in the 1970s and the 1980s, but their importance has declined over time. In most cases, the consultative bodies were modelled on the basis of how other associations and organizations had been included in politics. In Sweden, for instance, the corporatist arrangements in other policy sectors became the explicit model (cf. Ålund \& Schierup, 1991). Examples from other European states include the commission of racial equality in the UK, set up in relation to the Race Relations Act in the mid-1970s; the commission was an important consultative body for the government. In the Netherlands, a system of consultation was set up in the mid-1980s; in some cases, the Dutch government was obliged to consult with the national body representing immigrants. In several states, like the Netherlands and Sweden, ethnic associations have received funding and other types of support from the state (Odmalm, 2004; van Londen et al., 2007). In some states, there are few examples of consultation at the national level, but consultation exists at regional and local levels. Some associations and researchers have been rather critical of the consultation 
systems, arguing they have not provided avenues for immigrants to voice concerns and influence politics (Martiniello, 1999).

When looking at the forms of participation, it is also important to address how the mode of participation depends on the political system and other factors of relevance, such as incorporation policies and nationhood understandings. Koopmans et al. (2005) analyzed the characteristics of political claims-making by, against, and on behalf of immigrants in Britain, France, Germany, the Netherlands, and Switzerland. They showed there were significant effects in how claims-making was shaped depending on the citizenship and nationhood conception. They argued that this impact is shown with regard to what kind of issues are central to claims; for instance, entry and exit questions were very important in Germany and Switzerland, whereas discrimination and unfair treatment was central in Britain. It is also reflected in the status to which people refer when making claims, for instance, as ethnic groups or as immigrants. The action repertoires are affected by the openness of the political system; in systems where immigrants have better access to political participation and arenas for putting forward claims, the action repertoire is more moderate, whereas non-institutional, unconventional, and even violent forms of action are more common in more closed systems (Koopmans et al., 2005).

Contrary to what is common in debates concerning immigrant incorporation, Koopmans et al. found rather low levels of group-based claims made by immigrants, with the exception of Islamic groups (Koopmans et al., 2005, chapter 4). The shaping of actions and claims through the citizenship regime and nationhood understanding is less evident in relation to religious claims. The latter has attracted much attention over the past decade; some of the most discussed cases of conflicts around immigrant incorporation, such as the French headscarf debate, has centered on the place of Islam in European societies (cf. Benhabib, 2002: Joppke, 2010).

Immigrants who lack access to political institutions and who have an insecure legal and political status may also engage in political acts. One example of this is the immigrant mobilization taking place in Italy over recent years (Oliveri, 2012). In responding to a drive-by shooting that injured two immigrant workers, several hundreds of migrants from Africa, working as orange-pickers, rioted in the city of Rosarno in southern Italy in early 2010. This was the starting point for several other events (such as the strike "day without immigrants” in March 2010) and for mobilizations involving political parties and civil society 
organizations. Examples like these show that immigrants can act as citizens even when lacking several citizens' rights and resources, thereby also challenging images of migrants as passive victims (Oliveri, 2012).

\section{Citizenship and Economic Integration}

The first part of this section deals with factors affecting the individual's decision to naturalize. We will provide an update on studies that have tried to explain citizenship ascension in a number of countries. In general, the factors explaining naturalization can be traced from the individual level, the family- or group-level, and the country level. The second part of this section gives an account of the economic effects of citizenship ascension by the individual in a number of countries.

Who is naturalizing?

In his seminal paper, Yang (1994) argues that most studies explaining citizenship ascension have a starting point in immigrant integration that is seen as a determinant of naturalization. He distinguishes between two scholarly traditions. The first stresses the role of socioeconomic achievements in the naturalization process; the second emphasizes the importance of the immigrants' cultural adaption to the host society as well as their demographic characteristics. Yang notes that both traditions use immigrants' characteristics as predictors of the probability of naturalization, and both view naturalization as an outcome of the immigrant's successful integration into the receiving country. Another view to predict naturalization is a cost-benefit analysis, which is more in line with an economic view on the ascension of citizenship (Yang, 1994; Bevelander \& DeVoretz, 2008). Costs of naturalization could include the loss of citizenship status in the country of origin, implying, in turn, the possible loss of other rights, such as claiming inheritance or real estate in the country of origin. Other incurred costs connected to acquiring citizenship are the time and money invested in different kinds of courses and attached tests before and during the naturalization procedure. When it comes to the benefits of naturalization, the loss of one passport can be offset by the ability to obtain a new passport from the host country. If this country is a member of the EU, this also implies larger possibilities to travel and work in the EU. Naturalization also implies larger political rights to the individual, such as having voting rights in general elections. Finally, naturalization allows for employment opportunities in the 
civil service, the police, the justice system, and the military-areas normally reserved for nationals of a country. In other words, naturalization expands the pool of potential jobs for immigrants.

A number of studies have assessed the effects of individual characteristics on the propensity to naturalize. In the US (Kelley \& McAllistar, 1982; Portes \& Mozo, 1985; Liang, 1994), socioeconomic variables such as education, occupation, and income are suggested as important factors. Others see cultural and demographic factors as important determinants for naturalization (Barkan \& Khokov, 1980; Portes \& Curtis, 1987). Again others, Evans (1988) find for Australia that language proficiency and home ownership are affecting the propensity to naturalize. For Germany, (Hochman, 2011) language proficiency is not significant but finds positive effects on naturalization for political interest, period of stay, intention of stay, education and inter-ethnic relations like connections to other Germans. Yunju \& Wooksoo (2012) show that also changing institutional arrangements like welfare reforms can have an effect on the propensity to naturalize. Yang (1994) finds that cultural integration is more important than economic integration in the naturalization process in the US. Chiswick and Miller (2009) assess four factors affecting citizenship ascension: personal characteristics, visa category, country of origin features, and ethnicity of the neighborhood where immigrants live in destination country. Their results indicate effects connected to personal characteristics like higher level of schooling, proficiency in English, and service in the US Army. In relation to country of origin, they find a higher propensity of citizenship ascension for countries where it is relatively less attractive to be living in, both economically and politically, as well as for countries that allow dual citizenship. Controlling for individual characteristics, Dronkers and Vink (2012) try to assess the effect of citizenship policies on the propensity to naturalize for a number of European countries. Using multilevel analysis, they find that favorable citizenship policies positively affect the propensity to naturalize. However, immigrants from developing countries with unstable political regimes have a higher probability to naturalize than immigrants from other European countries. Individual characteristics like age, language proficiency, and years of residence are important indicators of citizenship uptake by immigrants. By and large, they reiterate the results in Chiswick and Miller's (2009) US study. Also, controlling for individual characteristics and using longitudinal data, Cort (2012) shows that the context of reception, the societal situation towards an ethnic group upon arrival to the country, in this case Latino's in Los Angeles, has an impact on the naturalization propensity. Finally, most of the studies on the ascension to 
citizenship are based on cross-sectional data and in principal measuring associations between dependent, the uptake of a new citizenship or not, and various independent variables. Few studies are using longitudinal data in which the causality between the variables can be measured and by this diminishing the positive selection into citizenship (cf. Bevelander \& Helgertz 2013 and Scott, 2008).

\section{Economic effects of citizenship ascension}

Over recent decades, a number of studies for different countries in the OECD have tried to measure the effect of citizenship ascension on the employment and earnings of immigrants. The following section will both discuss the outcomes of these studies in relation to the different settings and cover methodological issues in relation to how to measure the effect of citizenship.

Recently, several countries have changed their citizenship legislation with the intention of increasing the economic integration of immigrants. Several studies have been conducted on the effect that a change of citizenship has on the employment and incomes of immigrants over the same period (OECD, 2011, Bevelander \& DeVoretz, 2008). In more political terms, as discussed earlier, the granting of citizenship can be seen as an instrument in a socioeconomic integration process or as the end reward of such a process. Seen as a reward, a change of citizenship is dependent on a country's specific conditions for the actual change, for example, that the individual has acquired a basic proficiency in the new country's language and certain knowledge of laws and customs. This view of citizenship is closely associated with 'assimilation' - the idea that immigrants have adapted to the new society to an acceptable degree. In contrast, in a more 'multicultural' socio-political setting, a change of citizenship is emphasised as an instrument in the socioeconomic integration process (Corluy, Marx \& Verbist, 2011). Here, the actual naturalization process is seen as an integration tool, in which the individual finds his or her place in the new society by acquiring all the rights and obligations associated with the new citizenship.

The relation between naturalization and labor market integration of immigrants is complex and, to some extent, linked to other factors that affect integration. Some studies suggest there is a 'naturalization premium' (i.e., that immigrants who change their citizenship status have higher employment and income levels than the non-naturalized). The following literature review summarizes these studies according to country, methodology, and the factors that could give rise to 'the naturalization premium'. In general, studies on the relation in the 
US and Canada show a so-called 'naturalization premium', while studies for a number of European countries shows more mixed results (see Table XX).

Several factors have been suggested as explanations for the 'premium'. Some studies claim the premium is linked to potential employers' behavior and attitudes; employers are more inclined to recruit naturalized individuals because the transaction costs are lower for naturalized labor than for individuals who have only temporary work- and/or residence permits. Citizenship is seen as a signal to employers that the person in search of work intends to stay and settle permanently in the country and is prepared to invest in both human- and social capital. In other words, employing someone who is naturalized is regarded as less risky relative to an individual that is a non-citizen (Mazzolari, 2009). Mazzolari (2009) also found that individuals who come from countries that allow dual citizenship have an increase in employment and income.

Other factors considered as important in explaining the positive effect of citizenship on labor market integration are related to an individual profitability calculation. In some countries, only citizens of that country have the right to certain jobs. For example, some jobs in the public sector-such as in the police, in law, and in the military-are open only to those who are citizens of that country. Naturalization means the individual is eligible for this kind of work and is thereby able to improve her or his chances of obtaining work (Bratsberg et al., 2002; Yang, 1994). Having access to different occupations and sectors can lead also to greater professional mobility and a higher earned income (DeVoretz \& Pivnenko, 2006). In some countries, naturalization leads to other entitlements, such as unemployment benefits and social allowances.

Individuals who choose to change citizenship can also differ in other respects from those who do not naturalize. The effect of naturalization can also be intertwined with other factors that cannot be controlled for in the analysis (DeVoretz \& Pivnenko, 2008). More specifically, the change of citizenship can be regarded as a sign of a drawn-out integration process that is cultural, social, and linguistic. Related to this, Bevelander and Veenman (2006) found no effect of integration courses taken by immigrants on the probability to become Dutch or the probability to be employed in the Dutch labor market. Furthermore, the effect of a change of citizenship will exist before the actual change takes place. In addition to naturalization having a causal and positive selection effect on employment and incomes, Euwals et al. (2010) claim that a negative selection effect can also occur, meaning immigrants 
with weak socioeconomic profiles have a greater tendency to naturalize in order to be included in different welfare services.

Summarizing the studies that have examined the effect of citizenship on labor market outcomes, the analysis of immigration and naturalization has played a minor role in the field of economics for a long time. One exception is the early work by Chiswick (1978), in which he compared wages of foreign-born men with and without US citizenship, using crosssectional data from the 1970 US Census. He concluded that naturalized foreign-born men have higher average earnings than non-naturalized foreign-born men. However, controlling for the length of stay, the effect of naturalization on earnings becomes insignificant.

Contemporary studies of the impacts of citizenship acquisition by Bratsberg et al. (2002), Hayfron (2008), Scott (2008), Steinhardt (2008), Engdahl (2011), and Bevelander and Helgertz (2012) use longitudinal data to apply individual fixed effects models that control for self selection and both observable and non-observable characteristics. Contrary to Chiswick's (1978) seminal study, these studies find a positive impact of naturalization on wages even after controlling for time in the host country. Factors which could explain such an outcome include an individual's decision to invest in human capital or an employer's decision to view citizenship acquisition as an indicator of long-term commitment. Of course, in the short-run this investment may affect wages, but in the long-run the accumulation of human capital could result in higher wage levels. For the US, results by Bratsberg et al. (2002) suggest that citizenship acquisition reduces institutional labor market barriers, thereby increasing job opportunities for immigrants. In particular, they demonstrate an increase in the likelihood of public sector employment as a product of naturalization. Using cross-sectional data, DeVoretz and Pivnenko (2006, 2008) show that naturalized immigrants in Canada had higher earnings and, consequently, made larger contributions to the Canadian federal treasury than their non-naturalized counterparts. Similarly, Akbari (2008) found naturalized immigrants in the US in 2000 had increased treasury payments as well as higher rates of welfare participation. However, tax payments exceed transfer payments for naturalized immigrants after ten years of residence. Mazzolari (2009) found employment and earnings increased for naturalized Latin American immigrants in the US when their home countries passed dual citizenship laws and granted expatriates the right to naturalize in the receiving country.

Turning to Europe, recent research on Sweden by Bevelander and Pendakur (2012) point in the same direction. They assert that naturalization helps to improve the 
employment situation of refugees, particularly for those from lower income countries. Overall, empirical evidence indicates naturalization increases the labor market opportunities of immigrants and helps to facilitate the process of employment integration (see, for example, Bevelander \& Veenman (2008) for the Netherlands; Kogan (2003) comparing Austria and Sweden; Steinhardt (2008) for Germany; Steinhardt \& Wedemeier (2011) for Switzerland; and Kayaoglu \& Kaya (2011) comparing Germany and France). Corluy et al. (2011), examining immigrant outcomes in Belgium, find improved labor market outcomes for nonWestern immigrants in general.

Finally, in Table 1, we give an overview of studies that have analysed the effect of citizenship on the economic integration of immigrants. We structure this table according to the data that have determined the choice of analysis method; hence, the studies have been divided into cross-sectional and longitudinal data. Although all the studies have shown an awareness of the selection problem, they have not always taken this into account in the empirical analysis. In studies with cross-sectional data, different kinds of instruments have been included in order to reduce the effects of endogeneity. The same goes for longitudinal studies where it has been possible to control for differences in observed and unobserved individual characteristics.

Table 1. Review of studies on the effects of naturalization on labor market integration

\begin{tabular}{|c|c|c|c|}
\hline Data & & Employment & Earned income \\
\hline \multirow[t]{10}{*}{ Cross-sectional } & No control for selection effect & & \\
\hline & Chiswick (1978): USA & & $\mathbf{0}$ \\
\hline & Bratsberg et al. (2002): USA & & + \\
\hline & Kogan (2003): Austria and Sweden & $+\& 0$ & \\
\hline & Bevelander \& Veenman (2006 and 2008): The Netherlands & $0 \&+$ & + \\
\hline & DeVoretz \& Pivnenko (2006 and 2008): Canada & & + \\
\hline & Akbari (2008): 2008 & & + \\
\hline & Euwals et al. (2010): The Netherlands and Germany & $0 \&+$ & \\
\hline & Corluy et al. (2011): Belgium & + & \\
\hline & Steinhardt \&Wedemeier (2011): Switzerland & + & \\
\hline \multirow[t]{5}{*}{ Cross-sectional } & Control for selection effect & & \\
\hline & Bevelander \& Pendakur (2011): Sweden & + & \\
\hline & Bevelander \& Pendakur (2012): Canada and Sweden & + & + \\
\hline & Rallu (2011): France and the USA & + & \\
\hline & Kayaoglu \& Kaya (2011): Germany and France & $+\&+$ & \\
\hline \multirow[t]{8}{*}{ Longitudinal } & Bratsberg et al. (2002): USA & & + \\
\hline & Scott (2008): Sweden & & $\mathbf{0}$ \\
\hline & Fougère \& Safi (2009): France & + & \\
\hline & Hayfron (2008): Norway & + & \\
\hline & Steinhardt (2008): Germany & + & \\
\hline & Engdahl (2011): Sweden & & $\mathbf{0}$ \\
\hline & Bratsberg \& Raaum (2011): Norway & & $\mathbf{0}$ \\
\hline & Bevelander \& Helgertz (2012) & & $\mathbf{0}$ \\
\hline
\end{tabular}

\footnotetext{
$+=$ positive significant effect, $0=$ no significant effect
} 


\section{Conclusions}

In this article, we have dealt with several dimensions to immigration incorporation, discussing the regulation of access to legal status, rights, and citizenship as well as what may explain differences between states in this regard. We have also dealt with the factors that explain the propensity to naturalize and to what extent becoming a citizen has effects on employment and income. Whereas immigration is a phenomenon that affects almost all states in the world, there are significant differences between states when it comes to access to legal status, rights, and citizenship. In several democratic immigration states in Europe, North America, and Oceania, access to secure legal status, rights, and citizenship has been made easier after the Second World War. The political incorporation of immigrants was facilitated by changes of legislation and policies. However, during the last decade, several changes have been undertaken to make incorporation more difficult. Legal status has been made less secure and dependent on discretionary decisions in some states, and several states have introduced new criteria for becoming citizens, such as knowledge of language, politics, and history. At the same time, we see the continued liberalization of policies regarding dual nationality. As a result, it is difficult to ascertain where we are heading; there are signs both of increasing restrictions on incorporation and of making incorporation easier.

What incorporation policies make clear, however, is that although the more inclusive approach to incorporation, which characterized the 1950s to the 1990s, showed the increasing importance of jus domicilii in contrast to citizenship, this has not led to a postnational situation. We continue to live in a world in which residence and citizenship has major effects on persons' lives. States retain substantial power with respect to allowing entry to the territory, granting or denying access to status and rights, and-by implication of this-to opportunities and possibilities in society. 


\section{Literature}

Aguilar, Filomeno (1999). "The triumph of instrumental citizenship? Migrations, identities, and the nation-state in Southeast Asia”. Asian Studies Review, vol. 23, no. 3.

Akbari, A. H. (2008). Immigrant naturalization and its impacts on immigrant labor market performance and treasury. In The economics of citizenship, ed. Pieter Bevelander and Don J. DeVoretz. MIM/Malmö University. Malmö: Holmbergs.

Akyeampong, Emmanuel (2006). "Race, Identity and Citizenship in Black Africa: The Case of the Lebanese in Ghana.” Africa, vol. 76, no. 3, 297-323.

Alba, Richard \& Nancy Foner (2009). "Entering the Precincts of Power. Do National Differences Matter for Immigrant Minority Political Representation.” In Hochschild \& Mollenkopf (eds) Bringing Outsiders In. Transatlantic Perspectives on Immigrant Political Incorporation. Itahca: Cornell University Press, 277-293.

Anwar, Muhammad (2001). “The participation of ethnic minorities in British politics”. Journal of Ethnic and Migration Studies, vol. 27, no. 3, 533-549.

Ålund, Aleksandra \& Carl-Ulrik Schierup (1991). Paradoxes of Multiculturalism. Aldershot: Avebury.

Anderson, Bridget, Matthew Gibney \& Emanuela Paoletti (2011). “Citizenship, deportation, and the boundaries of belonging.” Citizenship Studies, vol. 15, no. 5, 547-563.

Barkan E.R. and N. Khokhlov. (1980). "Socioeconomic data as indices of naturalization patterns in the United States: A theory revisited”. Ethnicity, 7, 159-190.

Bass, Loretta \& Lynne Casper (1999). “Are There Differences in Registration and Voting Behavior Between Naturalized and Native-born Americans?” Washington, DC: U.S. Bureau of the Census, Population Division Working Paper 28.

Bauböck, Rainer (1994). Transnational Citizenship. Membership and Rights in International Migration. Aldershot; Edward Elgar.

Bäck, Henry \& Maritta Soininen (1998). Immigrants in the Political Process. Scandinavian Political Studies, vol. 21, no. 1, 29-50.

Bean, Clive (2012) "Democratic Participation in a Globalised World: Immigrants in Australia in the Early $21^{\text {st }}$ Century.” Australian Journal of Political Science, vol. 47, no 1, 115-131.

Benhabib, Seyla (2002). Claims of Culture. Equality and Diversity in the Global Era. Princeton: Princeton University Press.

Benhabib, Seyla (2004). The Rights of Others. Aliens, Residents, and Citizens. Cambridge: Cambridge University Press. 
Bertossi, Christophe \& Abdellali Hajjat (2012). “Country Report: France”. Florence: European University Institute.

Bevelander, P. and D. DeVoretz, eds. (2008). The economics of citizenship. MIM/Malmö University. Malmö: Holmbergs.

Bevelander, P. and J. Veenman (2006). Naturalization and immigrants' employment integration in the Netherlands. Journal of International Migration and Integration 7(3).

. (2008). Naturalisation and socioeconomic integration: The case of the Netherlands. RIIM and IZA discussion paper. In The economics of citizenship, ed. Pieter Bevelander and Don J. DeVoretz. MIM/Malmö University. Malmö: Holmbergs.

Bevelander, P. and R. Pendakur (2011a). Citizenship, Co-ethnic Populations, and Employment Probabilities of Immigrants in Sweden. Online Journal of International Migration and Integration. I-First.

Bevelander, P. and R. Pendakur (2011b). Voting and Social Inclusion in Sweden. International Migration, vol. 49 (4) August 2011, 67-92.

Bevelander, P. and R. Pendakur, 2012. Citizenship acquisition, employment prospects and earnings: comparing two cool countries. Working paper: Robert Schuman Centre, Florence.

Bevelander, P. and J. Helgertz, 2012. Är det lönsamt att bli medborgare? MIMEO, Malmö University.

Blatter, Joachim, Stefanie Erdmann \& Katja Schwanke (2012). “Acceptance of Dual Citizenship: Empirical Data and Political Contexts”. Luzern: Institute of Political Science, Universität Luzern.

Bloemraad, Irene (2006). Becoming a Citizen. Incorporating Immigrants and Refugees in the United States and Canada. Berkeley and Los Angeles: University of California Press.

Bohman, James (1996) Public Deliberation. Pluralism, Complexity, and Democracy. Cambridge, MA: MIT Press.

Bommes, Michael \& Andrew Geddes (Eds.) (2000). Immigration and Welfare. Challenging the borders of the welfare state. New York: Routledge.

Bonjour, Saskia (2011). “The Power and Morals of Policy Makers: Reassessing the Control Gap Debate”. International Migration Review, vol. 45, no. 1, 89-122.

Bratsberg, B., J. F. Ragan and Z. M. Nasir (2002). "The effect of naturalization on wage growth: A panel study of young male immigrants.” Journal of Labor Economics 20, 568-97. 
Bratsberg. Bernt \& Odd. Raaum. 2011. The Labor Market Outcomes of naturalized Citizens in Norway. In OECD (2011), Naturalisation: A Passport for the Better Integration of Immigrants?, OECD Publications.

Brubaker, Rogers (1992). Citizenship and Nationhood in France and Germany. Harvard: Harvard University Press.

Castles, Stephan \& Alastair Davidson (2000). Citizenship and Migration: Globalization and the Politics of Belonging. New York: Routledge.

Castles, Stephen \& Ellie Vasta (2004). “Australia: New Conflicts around Old Dilemmas.” In: W. Cornelius, T. Tsuda, P. Martin \& J. Hollifield (Eds.) Controlling Immigration. A Global Perspective. Stanford: Stanford University Press, 2 ed., 141-173.

Chiswick, B. (1978). The effect of Americanization on the earnings of foreign-born men. The Journal of Political Economy 86: 897-921.

Chiswick, Barry \& Paul. Miller (2009). Citizenship in the United States: The Roles of Immigrant Characteristics and Country of Origin, Research in Labor Economics, 29, 2009, 91-130.

Coll, Kathleen (2011). “Citizenship acts and immigrant voting rights movements in the US”. Citizenship Studies, vol. 15, no. 8, 993-1009.

Corluy, V and I Marx, G. Verbist. Employment chances and changes of immigrants in Belgium: the impact of citizenship. International Journal of Comparative Sociology, vol. 52(4), 350-368.

Cornelius, Wayne, Philip Martin \& James Hollifield (Eds.) (1994). Controlling Immigration. Stanford: Stanford University Press.

Costello, Cathryn (2012). "Human Rights and the Elusive Universal Subject: Immigration Detention under International Human Rights and EU Law”. Indiana Journal of Global Legal Studies, vol. 19, no. 1, 257-303.

Dahl, Robert (1989). Democracy and Its Critics. Yale: Yale University Press.

Dahlin, Eric \& Ann Hironaka (2008). "Citizenship beyond Borders: A Cross-National Study of Dual Citizenship”. Sociological Inquiry, vol. 78, no. 1, 54-73.

Davidson, Alastair (1999). “Open Republic, Multiculturalism and Citizenship: the French Debate”. Theory \& Event, vol 3, no 2.

D’Amato, Gianni (2009). “Swiss Citizenship: A Municipal Approach to Participation?” In J. Hochschild \& J. Mollenkopf (Eds.) Bringing Outsiders In. Transatlantic Perspectives on Immigrant Political Incorporation. Itahca: Cornell University Press, 63-73. 
Dronkers J. and M.P. Vink (2012). "Explaining Access to Citizenship in Europe: How Policies Affect Naturalisation Rates.” European Union Politics, vol. 13(3).

DeVoretz, D. J. and S. Pivnenko. 2006. The economic causes and consequences of Canadian citizenship. Journal of International Migration and Integration 6: 435-68.

- 2008. The economic determinants and consequences of Canadian citizenship ascension. In The economics of citizenship, ed. Pieter Bevelander and Don J. DeVoretz. MIM/Malmö University. Malmö: Holmbergs.

Engdahl, M (2011), The impact of naturalisation on Labor Market Outcomes in Sweden, in OECD (2011), Naturalisation: A Passport for the Better Integartion of Immigrants?, OECD Publications.

Entzinger, Jan (1999). Political and Social Participation of Immigrants through Consultative Bodies. Strasbourg: Council of Europe.

Ersböll, Eva (2010). “Country Report: Denmark”. Florence: European University Institute.

Euwals. R., J. Dagevos and M. Gijsberts. (2010). "Citizenship and labor market position: Turkish immigrants in Germany and the Netherlands.” International Migration Review 44(3): 513-538.

Faist, Thomas (Ed.) (2007). Dual Citizenship in Europe. From Nationhood to Societal Integration. Aldershot: Ashgate.

Faist, Thomas \& Peter Kivisto (2008). Dual Citizenship in Global Perspective: From Unitary to Multiple Citizenship. Houndmills: Palgrave Macmillan.

Fitzpatrick, Joan (2000). “Temporary Protection of Refugees: Elements of a Formalized Regime”. American Journal of International Law, vol. 94, no. 2, 279-306.

Fougère, D. and M. Safi. 2009. Naturalization and employment of immigrants in France (1968-1999). International Journal of Manpower 30(1/2): 83-96.

Fraga, Luis Ricardo (2009). "Building through Exclusion. Anti-Immigrant Politics in the United States”. In: J. Hochschild \& J. Mollenkopf (Eds.) Bringing Outsiders In. Transatlantic Perspectives on Immigrant Political Incorporation. Cornell: Cornell University Press, 176-192.

Freeman, Gary (1994). “Can Liberal States Control Unwanted Migration?” Annals of the American Academy of Political and Social Science, 534: 17-30.

Freeman, Gary (1998). “The Decline of Sovereignty? Politics and Immigration Restriction in Liberal States”. In C. Joppke (Ed.) Challenges to the Nation-State. Immigration in Western Europe and the United States. Oxford: Oxford University Press, 86-108. 
Freeman, Gary (2004). "Immigrant Incorporation in Western Democracies”. International Migration Review, vol. 38, no. 3, 945-969.

Freeman, Gary (2006). "National models, policy types, and the politics of immigration in liberal democracies”. West European Politics, vol. 29, no. 2: 227-247.

Fundamental Rights Agency (2011). Fundamental rights of migrants in an irregular situation in the European Union. Vienna: European Union Agency for Fundamental Rights.

Gerdes, Jürgen, Thomas Faist \& Beate Rieple (2007). “'We are All Republican Now: The Politics of Dual Nationality in Germany” In: T. Faist (Ed.) Dual Citizenship in Europe. From Nationhood to Societal Integration (Aldershot: Ashgate), 45-76.

Gibney, Matthew (2004). The Ethics and Politics of Asylum. Liberal Democracy and the Response to Refugees. Cambridge: Cambridge University Press.

Goldring, Luin, Carolina Berinstein \& Judith Bernhard (2009). "Institutionalizing precarious migratory status in Canada”. Citizenship Studies, vol. 13, no. 3: 239-265.

Goldston, James (2006). "Holes in the Rights Framework: Racial Discrimination, Citizenship, and the Rights of Noncitizens”. Ethics and International Affairs, vol. 20, no. 3, 321-347.

Goodman, Sara Wallace (2010). "Naturalisation Policies in Europe: Exploring Patterns of Inclusion and Exclusion”. Florence: European University Institute.

Gorny, Agata, Aleksandra Grzymala-Kazlowska, Piotr Korys \& Agnieszka Weinar (2007). Selective Tolerance? Regulations, Practice and Discussions Regarding Dual Citizenship in Poland”. In: T. Faist (Ed.) Dual Citizenship in Europe. From Nationhood to Societal Integration. Aldershot: Avebury, 147-170.

Green, Simon (2012). "Much ado about not-very-much? Assessing ten years of German citizenship reform”. Citizenship studies, vol. 16, no. 2, 173-188.

Groenendijk, Kees, Elspeth Guild \& Halil Dogan (1998). Security of Residence of LongTerm Migrants. A Comparative Study of Law and Practice in European Countries. Strasbourg: Council of Europe.

Groenendijk, Kees (2008). Local Voting Rights for Non-Nationals in Europe. What We Know and What We Need to Learn. Washington, DC: Migration Policy Institute.

Guiraudon, Virginie (1998). “Citizenship Rights for Non-Citizens: France, Germany, and the Netherlands”. In: C. Joppke (Ed.) Challenges to the Nation-State. Immigration in Western Europe and the United States. Oxford: Oxford University Press, 272-318.

Gustafson, Per (2002). "Globalisation, multiculturalism and individualism: The Swedish debate on dual citizenship.” Journal of Ethnic and Migration Studies, vol. 28, no. 3, 463-481. 
Habermas, Jürgen (1992). Faktizität und Geltung. Beiträge zur Diskurstheorie des Rechts und des demokratischen Rechtsstaats. Frankfurt a. M.: Suhrkamp.

Hailbronner, Kay (2010). “Country Report: Germany.” (Florence: European University Institute).

Hammar, Tomas (1990). Democracy and the Nation State: Aliens, Denizens, and Citizens in a World of International Migration. Aldershot: Avebury.

Hansen, Randall \& Jobst Koehler (2005). "Issue definition, political discourse and the politics of nationality reform in France and Germany”. European Journal of Political Research, vol. 44, 623-644.

de Hart, Betty \& Ricky van Oers (2006). "European trends in nationality law”. In: R. Bauböck, E. Ersböll, K. Groenendijk \& H. Waldrauch (Eds.) Acquisition and Loss of Nationality, volume 1: Comparative Analyses. Amsterdam: Amsterdam University Press, 317-358.

de Hart, Betty (2007). "The End of Multiculturalism: The End of Citizenship? Political and Public Debates on Dual Citizenship in the Netherlands (1980-2004)”. In: T. Faist (Ed.) Dual Citizenship in Europe. From Nationhood to Societal Integration. Aldershot: Averbury, 77102.

Hayfron J. E. 2008. The economics of Norwegian citizenship. In The economics of citizenship, ed. Pieter Bevelander and Don J. DeVoretz. MIM/Malmö University. Malmö: Holmbergs.

Hochschild, Jennifer \& John Mollenkopf (2009). "Modeling Immigrant Political Incorporation”. In: J. Hochschild \& J. Mollenkopf (Eds.) Bringing Outsiders In. Transatlantic Perspectives on Immigrant Political Incorporation. Itahca: Cornell University Press, 15-30.

Hofhansel, Claus (2008). "Citizenship in Austria, Germany, and Switzerland: Courts, Legislatures, and Administrators”. International Migration Review, vol. 42, no. 1, 163-192.

Hollifield, James (2004). “The Emerging Migration State”. International Migration Review, vol. 38, no. 3, 885-912.

Howard, Marc (2005). "Variation in Dual Citizenship Policies in the Countries of the EU”. International Migration Review, vol. 39, no. 3, 697-720.

Human Rights Watch (2009). Lost in Transit. Insufficient Protection for Unaccompanied Migrant Children at Roissy Charles de Gaulle Airport. New York: Human Rights Watch.

Ireland, Patrick (1989). "The State and the Political Participation of the 'New' Immigrants in France and the United States”. Revue francaise d’etudes américaines, no. 41, 315-328. 
Jacobson, David (1996). Rights across Borders. Immigration and the Decline of Citizenship. Baltimore: Johns Hopkins University Press.

Jones-Correa, Michael (2001). “Under Two Flags: Dual Nationality in Latin America and Its Consequences for Naturalization in the United States”. International Migration Review, vol. 35, no. 4, 997-1029.

Joppke, Christian (1998a). "Why Liberal States Accept Unwanted Immigration.” World Politics, vol. 50, no. 2, 266-293.

Joppke, Christian (1998b). Immigration and the Nation-State. The United States, Germany, and Great Britain. Oxford: Oxford University Press.

Joppke, Christian (1999). “The Domestic Legal Sources of Immigrant Rights: The United States, Germany, and the European Union”. Florence: European University Institute, EUI Working paper no 99/3.

Joppke, Christian (2010). Citizenship and Immigration. Cambridge: Polity.

Just, Aida \& Christopher Anderson (2012). "Immigrants, Citizenship and Political Action in Europe”. British Journal of Political Science, vol. 42, no. 3, 481-509.

Kastoryano, Riva (2010). "Negotiations beyond Borders: States and Immigrants in Postcolonial Europe”. Journal of Interdisciplinary History, vol. 41, no. 1: 79-95.

Kayaoglu, A. And A. Kaya. 2011. Is National Citizenship Withering Away?: Social Affiliations and Labor Market Integration of Turkish Origin Immigrants in Germany and France. University of Louvain Discussion paper 2011:33.

Kelley, J. and I. McAllister. 1982. The decision to become an Australian citizen. Australian and New Zealand Journal of Sociology, 18: 428-439.

Kivisto, Peter \& Thomas Faist (2007). Citizenship: Discourse, Theory, and Transnational Prospects. Oxford: Blackwell.

Kogan, I. 2003. Ex-Yugoslavs in the Austrian and Swedish labor markets: The significance of period of migration and the effect of citizenship acquisition. Journal of Ethnic and Migration Studies 29: 595-622.

Koopmans, Ruud, Paul Statham, Marco Giugni, and Florence Passy (2005). Contested Citizenship. Immigration and Cultural Diversity in Europe. Minneapolis: University of Minnesota Press.

Koopmans, Ruud, Ines Michalowski, and Stine Waibel (2012). "Citizenship Rights for Immigrants: National Processes and Cross-National Convergence in Western Europe, 19802008”. American Journal of Sociology, vol. 117, no. 4, 1202-1245. 
Koser, Khalid \& Richard Black (1999). "Limits to Harmonization: The "Temporary Protection” of Refugees in the European Union”. International Migration, vol. 37, no. 3, 521543.

Kymlicka, Will (2012). "Multiculturalism: Success, Failure, and the Future”. Washington, DC: Migration Policy Institute.

Kymlicka, Will \& Wayne Norman (Eds.) (2000). Citizenship in Diverse Societies. Oxford: Oxford University Press.

Layton-Henry, Zig (2004). “Britain: From Immigration Control to Migration Management”. In: W. Cornelius, T. Tsuda, P. Martin \& J. Hollfield (Eds.) Controlling Immigration. A Global Perspective. Stanford: Stanford University Press, 2 ed: 297-333.

van Londen, Marieke, Karen Phalet \& Louk Hagendoorn (2007). "Civic Engagement and Voter Partipcation among Turkish and Moroccan Minorities in Rotterdam”. Journal of Ethnic and Migration Studies, vol. 33, no. 8: 1201-1226.

Manby, Bronwen (2010). Citizenship Law in Africa. A Comparative Study. New York: Open Society Foundation.

Mamdani, Mahmood (1996). Citizen and Subject: Contemporary Africa and the Legacy of Late Colonialism. Princeton: Princeton University Press.

Martiniello, Marco (1999). "The limits of consultative politics for immigrants and ethnic immigrant minorities.” In: Han Entzinger (Ed.) Political and Social Participation of Immigrants through Consultative Bodies. Strasbourg: Council of Europe.

Martiniello, Marco (2006) "Political participation, mobilisation and representation of immigrants and their offspring in Europe”. In R. Bauböck (Ed.) Migration and Citizenship. Legal Status, Rights and Political Participation. Amsterdam: Amsterdam University Press, 83105.

Maxwell, Rahsaan (2010). "Political Participation in France among Non-European-Origin Migrants: Segregation or Integration?” Journal of Ethnic and Migration Studies, vol. 36, no. 3, 425-443.

Mazzolari, F. 2009. Dual citizenship rights: Do they make more and better citizens? Demography, 46, 169-191.

Menz, Georg \& Alexander Caviedes, ed. (2010). Labor Migration in Europe. Houndmills: Palgrave.

Michalowski, Ines (2011). "Required to assimilate? The content of citizenship tests in five countries”. Citizenship Studies, vol. 15, no. 6-7, 749-768.

MIPEX (2010), Migration Integration Policy Index. Brussels: British Council and Migration Policy Group. 
Niessen, Jan \& Thomas Huddleston (Eds.) (2009). Legal Frameworks for the Integration of Third-Country Nationals. Leiden: Martinus Nijhoff.

Odmalm, Pontus (2004). "Civil society, migrant organisations and political parties; theoretical linkages and applications to the Swedish context”. Journal of Ethnic and Migration Studies, vol. 30, no. 3: 471-489.

OECD (2011). Naturalisation: A Passport for the Better Integration of Immigrants?, OECD Publications.

Oliveri, Federico (2012). "Migrants as activist citizens in Italy: understanding the new cycle of struggles”. Citizenship Studies, vol. 16, no. 5, 793-806.

Piper, Nicola (2004). "Rights of Foreign Workers and the Politics of Migration in South-East and East Asia”. International Migration, vol. 42, no. 5, 71-97.

Portes, A. and J.W. Curtis (1987). "Changing flags: naturalization and its determinants among Mexican immigrants”. International Migration Review, 21: 352-371.

Portes, A., and R. Mozo (1985). "The political adaptation process of Cubans and other ethnic minorities in the United States: A preliminary analysis”. International Migration Review, 16:35-63.

Ramakrishnan, Karthick \& Thomas Espenshade (2001). “Immigrant Incorporation and Political Participation in the United States”. International Migration Review, vol. 35, no. 3, 870-909.

Reitz, Jeffrey (2004). "Canada: Immigration and Nation-Building in the Transition to a Knowledge Economy”. In W. Cornelius, T. Tsuda, P. Martin \& J. Hollfield (Eds.) Controlling Immigration. A Global Perspective. Stanford: Stanford University Press, 2 ed, 97-133.

Rallu, J.L. (2011). “Naturalization Policies in France and the USA and Their Impact on Migrants’ Characteristics and Strategies”. Population Review 50(1), 40-61

Rooij, Eline (2012). "Patterns of Immigrant Political Participation: Explaining Differences in Types of Political Participation between Immigrants and the Majority Population in Western Europe”. European Sociological Review, vol. 28, no. 4, 455-481.

Rubio Marin, Ruth \& Irene Sobrino (2010). “Country Report: Spain”. Florence: European University Institute.

Sager, Maja (2011). Everyday Clandestinity: Experiences on the Margins of Citizenship and Migration Policies. Lund: Lund University.

Sandesjö, Håkan \& Kurt Björk (2005). Nya medborgarskapslagen. Stockholm: Norstedts. 
Sandovici, Maria Elena \& Ola Listhaug (2010). "Ethnic and Lingustic Minorities and Political Particpation in Europe”. International Journal of Comparative Sociology, vol. 51, no.1-2: 111136.

Sawyer, Caroline (2010). “Country Report: United Kingdom”. Florence: European University Institute.

Schuck, Peter (1998). “The Re-Evaluation of American Citizenship”. In: C. Joppke (Ed.) Challenges to the Nation-State. Immigration in Western Europe and the United States. Oxford: Oxford University Press, 191-230.

Scott, K. 2008. The economics of citizenship: Is there a naturalization effect? In The economics of citizenship, ed. Pieter Bevelander and Don J. DeVoretz. MIM/Malmö University. Malmö: Holmbergs.

Sejersen, Tanja (2008). “'I Vow to Thee My Countries' - The Expansion of Dual Citizenship in the 21st Century,” International Migration Review, vol. 42, no. 3, 523-549.

Soysal, Yasemin (1994). Limits of Citizenship. Migrants and Postnational Membership in Europe. Chicago: University of Chicago Press.

Spiro, Peter (1997). "Dual Nationality and the Meaning of Citizenship”. Emory Law Review, vol. 46, no. 4, 1411-1485.

Spång, M. 2007. "Pragmatism All the Way Down? The Politics of Dual Citizenship in Sweden”. In T. Faist (Ed.) Dual Citizenship in Europe. From Nationhood to Societal Integration. Aldershot: Ashgate, 103-126.

Steinhardt, M. F. 2008. Does citizenship matter? The economic impact of naturalizations in Germany. Centro Studi Luca D’Agliano Development Studies Working Paper

Steinhardt, M.F. and Wedemeier, J (2011). "The Labor Market Performance of Naturalized Immigrants in Switzerland - New Findings from the Swiss Labor Force Survey”. Journal of International Migration and Integration, I-First.

Strömblad, Per \& Per Adman (2009). "Political Integration through Ethnic or Nonethnic Voluntary Associations?” Political Research Quarterly, vol. 63, no. 4: 721-730.

Surak, Kristin (2008). “Convergence in Foreigner’s Rights and Citizenship Policies? A Look at Japan”. International Migration Review, vol. 42, no. 3, 550-575.

Togeby, Lise (1999). "Migrants at the polls: An analysis of immigrant and refugee participation in Danish local elections.” Journal of Ethnic and Migration Studies, vol. 25, no. 4: 665-684. 
Togeby, Lise (2004). "It Depends ... How Organisational Participation Affects Political Participation and Social Trust among Second-Generation Immigrants in Denmark”. Journal of Ethnic and Migration Studies, vol. 30, no. 3, 509-528.

Verba, Sidney, Kay Lehman Schlozman \& Henry Brady (1995). Voice and Equality: Civic Voluntarism in American Politics. Cambridge, MA: Harvard University Press.

Weil, Patrick (2001). “Access to Citizenship - A Comparison of Twenty-Five Nationality Laws”. In: A. Aleinikoff \& D. Klusmeyer (Eds.) Citizenship Today. Global Perspectives and Practices. Washington: Carnegie Endowment for International Peace.

Weiler, J. H. H. \& Marlene Wind (Ed.) (2003). European Constitutionalism beyond the State. Cambridge: Cambridge University Press.

Whitaker, Beth Elise (2011). "The Politics of Home: Dual Citizenship and the African Diaspora”. International Migration Review, vol. 45, no. 4: 755-783.

White, Stephen, Neil Nevitte, André Blais, Elisabeth Gidengil \& Patrick Fournier (2008). “The Political Resocialization of Immigrants. Resistance or Lifelong Learning?” Political Research Quarterly, vol. 61, no. 2, 268-281.

United Nations (2003). "Prevention of Discrimination. The Rights of Non-citizens. Final Report of the Special Rapporteur, Mr David Weissbrodt”. Economic and Social Council, E/CN.4/Sub2/2003/23.

US Government (2001). Citizenship Laws of the World. Washington: United States Office of Personnel Management Investigations Service.

Yang, P.Q. 1994. Explaining immigrant naturalization. International Migration Review, 28: 449-77

Ziemele, Ineta (2005). State Continuity and Nationality: The Baltic States and Russia. Leiden: Brill. 